\title{
WestVirginiaUniversity
}

THE RESEARCH REPOSITORY @ WVU

Graduate Theses, Dissertations, and Problem Reports

2017

\section{Intersectionality Effects on Veterans Health Outcomes}

James M. Conley

Follow this and additional works at: https://researchrepository.wvu.edu/etd

\section{Recommended Citation}

Conley, James M., "Intersectionality Effects on Veterans Health Outcomes" (2017). Graduate Theses, Dissertations, and Problem Reports. 5386.

https://researchrepository.wvu.edu/etd/5386

This Thesis is protected by copyright and/or related rights. It has been brought to you by the The Research Repository @ WVU with permission from the rights-holder(s). You are free to use this Thesis in any way that is permitted by the copyright and related rights legislation that applies to your use. For other uses you must obtain permission from the rights-holder(s) directly, unless additional rights are indicated by a Creative Commons license in the record and/ or on the work itself. This Thesis has been accepted for inclusion in WVU Graduate Theses, Dissertations, and Problem Reports collection by an authorized administrator of The Research Repository @ WVU. For more information, please contact researchrepository@mail.wvu.edu. 


\title{
INTERSECTIONALITY EFFECTS ON VETERANS HEALTH OUTCOMES
}

\author{
James M. Conley
}

\author{
Thesis submitted \\ to the Eberly College of Arts and Sciences \\ at West Virginia University \\ in partial fulfillment of the requirements for the degree of \\ Master of Arts in \\ Sociology
}

Jeralynn S. Cossman, Ph.D., Chair

Lisa M. Dilks, Ph.D.

Joshua M. Woods, Ph.D.

Department of Sociology and Anthropology

Morgantown, West Virginia

2017

Keywords: feminism, intersectionality, minority stress, veterans, veterans health Copyright 2017 James M. Conley 


\title{
ABSTRACT \\ INTERSECTIONALITY EFFECTS ON VETERANS HEALTH OUTCOMES
}

\author{
James M. Conley
}

This paper examines the combined influence of racial minority and sexual minority statuses on the health outcomes of US military veterans. I describe the effect of multiple minority statuses on reported health indicators from a nationally representative survey instrument. The data used for this study comes from 20 US states which elected to include an optional, but standardized, module on sexual orientation as part of the 2014 Behavioral Risk Factor Surveillance System (BRFSS) and 21 US states which elected to use that same module in the 2015 BRFSS. The sample of analysis contains 35,163 respondents who identified as US military veterans, of whom 3,135 are female, 5,763 are racial minorities, and 910 are sexual minorities. Respondents are described by their selfreported health on a standardized survey question administered in the BRFSS survey instrument, and by demographic control variables for age, education, and income. This study is informed by and will contribute to the existing literature of intersectionality and minority stress, which predicts interaction effects among the negative associations of disadvantaged statuses. For this study, relevant subsamples of minority respondents are analyzed and the association of their minority statuses are compared for interaction effects on self-reported health; e.g., female sexual minority veterans $(n=193)$, non-White female veterans $(n=911)$. 


\section{DEDICATION}

The author wishes to dedicate this study to veterans of the United States armed forces - every man and woman who at one point in his or her life signed a blank check made payable to the United States of America for an amount of up to and including his or her life. 


\section{ACKNOWLEDGEMENTS}

The author wishes to acknowledge the assistance, feedback, and support of Drs. Jeralynn Cossman, Lisa Dilks, and Joshua Woods throughout the process of conception and writing. 
TABLE OF CONTENTS

\section{Table of Contents}

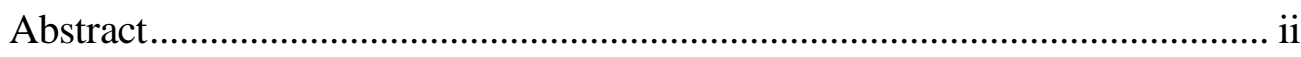

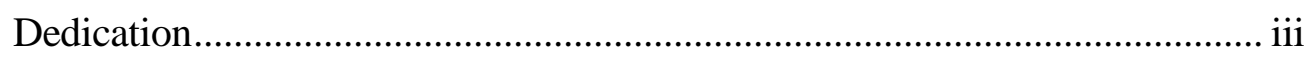

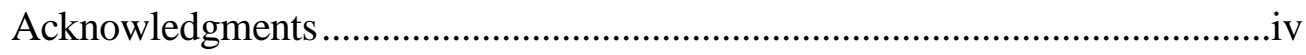

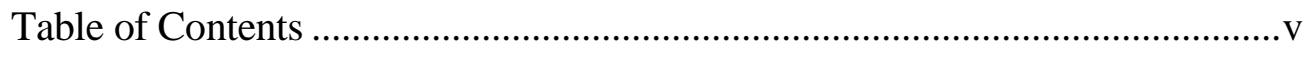

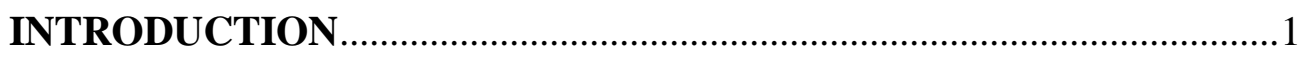

CHAPTER 1: LITERATURE REVIEW ......................................................

CHAPTER 2: STATEMENT OF PROBLEM ................................................

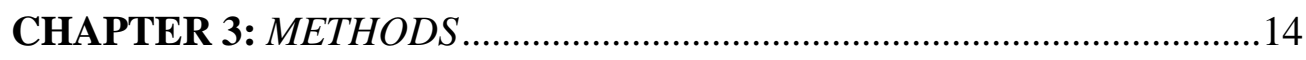

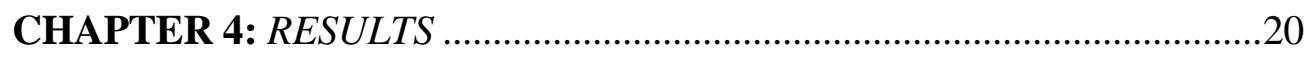

CHAPTER 5: CONCLUSIONS AND DISCUSSION …................................27

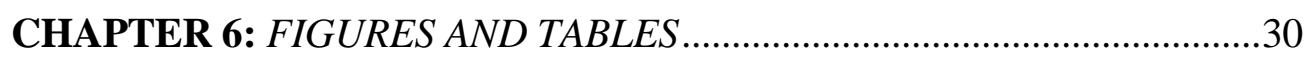

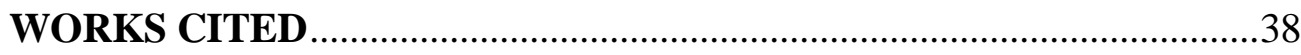




\section{IN T R O D UCTION}

The dominant culture of the United States is and always has been white, male, and straight, ever since the days of the nation's founding. There was not a single Black or female signatory to the Declaration of Independence, and the country would not see a Black congressperson until Reconstruction brought Senator Hiram Rhodes Revels in 1870 (Byrd); nor a woman holding national office until the election of Jeannette Pickering Rankin to the House of Representatives in 1916 (van Assendelft 1998); nor an openly gay person elected to either house of the Congress as a non-incumbent until the election of Tammy Baldwin to the House of Representatives in 1998 (Grinberg 2012). The history of this country is replete with examples of minority groups treated as subordinate - starting with the Three-Fifths Compromise at the Continental Congress and institutional slavery, to women's suffrage and the Civil Rights era, through to the present with Black Lives Matter and the ongoing dialogue concerning gay and transgender rights. Further, the election of a Black president in 2008 and his reelection in 2012 does not constitute a lack of enduring racial prejudice and discrimination. White, straight men continue to enjoy by default a privileged position in our society and its institutions, and everyone else is some manner of minority - whether numerically or subordinately. In the armed forces especially, a culture that glorifies masculinity subordinates the feminine, the gender-nonconforming, and the non-straight to an extent even greater than in the general population (Kerrigan 2012).

Among the general population, overt discrimination and institutional prejudice are generally perceived in the public conscience and depicted in popular media as immoral, 
negative behaviors. Racism, sexism, and so on, are generally considered personal flaws, and federal law has for decades prohibited their overt exercise in areas such as education, employment, lending, and housing decisions; e.g., the Civil Rights Act of 1964, the Fair Housing Act, and various titles of the United States Code. Despite protections for certain minority statuses, other statuses are not protected; for example, there is to date no federal statute that prohibits discrimination based on gender identity or sexual orientation, and many states still have antiquated, and hitherto unchallenged, sodomy laws which append a criminal infraction to at least male homosexual intimacy. Groups such as the Human Rights Campaign, and other allies of gay and transgender rights, are pushing for changes to federal law that would extend federal protections to these populations, and already successes have been won in acknowledging the benefits and rights of certain populations (Rein 2015, Savage 2013). But the military has always been a different kind of institution. Owing to its unique requirements for uniformity, order, and discipline, and to be constantly ready for combat, the armed forces have historically been exempted from many federal regulations such as those mentioned above. It has been argued, both in the contemporary era and in the past, that the stringent requirements and unique mission of the military must trump the civil liberties of its members - in the interest of national security and warfighting effectiveness (e.g.; Shilts 1993/2005; United States v. Marcum, United States v. Stirewalt). It is with this understanding that I approach issues of minority military veterans.

Until recently, gay, lesbian, and bisexual (GLB) individuals were prohibited by Defense Department regulation from serving openly in the U.S. armed forces (DOD Instruction 1304.26). At the time of writing, transgender individuals remain unable to openly serve in the military due to Defense Department regulation (DOD Instruction 
6130.03). Due to both hostile culture within the institution and potentially career-ending consequences for disclosure, research on the experiences and health outcomes of GLB veterans and active duty service members has been relatively scarce.

The current study proposes to address a clear deficiency in the literature. I analyze the subsamples of veterans who responded to the 2014 and 2015 Behavioral Risk Factor Surveillance System (BRFSS) questionnaires to compare self-reported health among and between the subpopulation of GLB veterans and their straight peers, as well as GLB and straight non-veterans. I also compare these indicators and factors among and between the categories of racial minority status and sex. These comparisons are presented, with and without control variables for age, education, and income, in Chapter 4.

Existing literature on intersectionality theory and the minority stress model inform my expectations that respondents who are members of one or more disadvantaged groups report worse health indicators and more frequent risk factors than their peers who are in fewer or no minority groups. The current study investigates these hypotheses as they relate specifically to the population of GLB veterans. 


\section{H A P T E R 1: LITERATURE REVIEW}

Gender and sexual minority issues have received great attention from the general public in recent years due to the ongoing political discussion of the gay rights and marriage equality movements in popular media and as political issues (e.g., Gray 2015, Leland 2016, Martin 2016, Peters 2016, Reilly 2016). This ongoing dialogue notably includes the end of the "Don't Ask, Don't Tell" (DADT) policy on 20 September 2011, and the 26 June 2015 ruling of the U.S. Supreme Court in Obergefell v. Hodges that made same-sex marriage legal across the United States. Changes in law and policy obviously have far-reaching implications for both active duty service members and veterans, their families, and for the military and other government institutions in areas such as benefits eligibility, regulations, and interactions between civilian and military law and policies (e.g., Garamone 2011, Parrish 2013, Savage 2013, Wax-Thibodeaux 2014, Phillips 2015, Rein 2015). Relevant to this paper, the federal Department of Veterans Affairs (VA) in general, and specifically the Veterans Health Administration (VHA), has in recent years begun preparing to address the health care needs of a growing number of GLB veterans. As a step toward predicting GLB health care needs, the VA has labeled the GLB veterans population "of special interest," and has commissioned and/or cooperated with several studies to estimate their numbers and to identify any unique health outcomes and risk factors among the population (e.g., Shipherd 2012, Blosnich 2013, Mattocks 2013, Simpson 2013, Sherman 2014). Research conducted on census data in previous years by authors such as Gates (2004) and Shipherd (2014) estimate the current population of LGBT military veterans in the United States at around 1 million individuals. 
While certain other subpopulations of U.S. military veterans have been the subject of extensive and varied research interest in the fields of medicine and psychology—such as veterans of the Post-9/11 conflicts in Afghanistan and Iraq (e.g., Beaulieu 2015, Brett 2009, Lew 2009, Pietrzak 2011), relatively few studies have investigated LGBT veterans. Even fewer studies attempt to address the compounding effects of racial minority status on gender or sexual minority status, and these few existing studies are of limited usefulness due to their reliance on small sample sizes and/or snowball samples, or other nonrepresentative samples of convenience (e.g., Blosnich 2013, Mattocks 2013). The scarcity of research in this area is due in part to the difficulty of collecting large, representative samples of minority veterans. Respondent fear of disclosure persists among both active duty military and veterans even after the repeal of the DADT policy, which until 2012 prevented GLB individuals from serving openly in the armed forces. At the time of writing, transgender individuals still cannot serve openly in the military due to regulations in each branch of service that discriminate against psychosexual conditions or genital defects among current or potential military service members (DOD Instruction 6130.03). Kerrigan (2012) proposes that the "maleness" of the military and the broad discretion granted to commanders under article 134 of the Uniform Code of Military Justice has resulted in the need for active duty service members to hide their gender or sexual minority status or nonconformity for fear of harassment or unwanted discharge from the armed forces. It is reasonable to assume, and it has been demonstrated that, these fears persist even after individuals transition from active duty to veteran status and thus influence interview and focus group responses (e.g., Moradi 2009). 
The respondent fear of disclosure revealed in focus group interviews is especially problematic from the perspective of the VA. Sherman et al (2014) report that the majority of LGBT veterans who were interviewed in focus groups have not disclosed their sexual orientation $(62 \%)$ or gender identity $(81 \%)$ to VA health care providers, and feel that VA providers should never assess or "ask" about their gender identity or sexual orientation unless the patient first voluntarily "tells" (59\%). Focus group participants have expressed fear of discrimination or stigma — consistent with minority stress literature above; loss of benefits for themselves or their families; and, lower quality of care or refusal of treatment from VA providers-should they reveal sexual minority status (Seaver 2008, Mattocks 2013, Sherman 2014, O’Brien 2015). These beliefs, while not in accordance with official VA policy, reflect reported experiences across multiple studies and constitute barriers to health care utilization (e.g.,Moradi 2009, Shipherd 2012, Simpson 2013, O’Brien 2015). And these fears are not entirely unwarranted. Seaver (2008) found that lesbian and bisexual veterans reported "discrimination, rejection, and/or poor care" after their VA providers learned of their sexual minority status.

From these findings, we must assume that underreporting has contributed at least in part to the dearth of useable data available to the VA among GLB veterans, and among transgender veterans especially—who experience the most perceived stigma for their sexual minority status. Meaningfully assessing the health care access, usage, and quality of care for these subpopulations of U.S. military veterans has been impossible due to the resultant lack of available data for these populations. The current study proposes to avoid involvement with the VA entirely, and in so doing to hopefully avert the underreporting problem that prior, VA-coordinated studies have encountered. 


\section{Health Disparities}

The CDC (2008) defines health disparities as "preventable differences in the burden of disease, injury, violence, or opportunities to achieve optimal health that are experienced by socially disadvantaged populations," and the National Institutes of Health (NIH) offers a timeline of research on health disparities among minority populations with topics such as incidence of cancer, cardiovascular disease, and HIV/AIDS with reference to education and other social determinants of health outcomes (NIH 2010). In general, the CDC and $\mathrm{NIH}$ report that health disparities occur, at least in part, due to inequalities in education and health care access, living in poverty, and personal behavioral risk factors-claims which are supported by numerous studies in the literature of public health (see, for example: Adler 2002; Braveman 2006, 2010; Chomitz 2009; Ellickson 1997; Jemal 2008; Krieger 2003; Lasser 2006; McCarty 2008; Stuart 2008). In general, health disparities are significant not only as social problems per se but also as indicators of social inequalities.

And these inequalities do not occur in a vacuum. Implicit in several of the above studies is the acknowledgement that ethnic or racial minorities, and sexual minorities, are more likely to experience health disparities because of various stressors (see, for example: Fiscella 2002, Flaskerund 2002, Fredriksen-Goldsen 2013, Keppel 2007, LaVeist 2005, Mustanski 2015, Orsi 2010, Smedley 2003). Here, the public health literature on health disparities and the social sciences literature on minority stress agree and overlap, with such authors as Blosnich (2010, 2013b), Cummings (2008), Gilman (2001), Mays (2001, 2002), Meyer (1995, 2003), and Newcomb (2014) noting strong association between minority status and the likelihood of experiencing negative health outcomes which constitute health disparity in those populations. 


\section{H A P T E R 2: STATEMENT OF PROBLEM}

Supporting the assertion that health disparities exist among minority populations are numerous studies that investigate particular minority statuses and/or combinations of minority status. Researchers have found that ethic/racial minorities receive lower quality care from medical providers (e.g., Brach 2000, Burgess 2006, Green 2007, Van Ryn 2000) and have less access to health care services and preventive medicine (Lasser 2006, Smedley 2002). Disparities in health care access and service quality also occur among sexual minorities (e.g., Benson 2013, Blosnich 2013a, Lasser 2006). Particularly among women, disparities in health outcomes are correlated with ethnic/racial minority status (Bowleg 2008, Cummings 2008, Mays 2002) and sexual minority status (Blosnich 2013b, Burgard 2005, Fredriksen-Goldsen 2013, Mattocks 2013, Seaver 2008). Disparity in health outcomes, health care access, and quality of care are all concerns for organizations such as the CDC, the NIH, and the World Health Organization.

Military veterans are a minority population in the numerical sense. And while veterans are not generally considered a subordinate minority, the unique nature of military service predisposes service members to a greater likelihood of suffering certain health conditions to include ALS (Haley 2004, Horner 2004), PTSD (Bedi 2007, Nayback 2008, Polusny 2014), and sleep apnea (Colvonen 2015, Vanden Brook 2010). Beyond the specific health outcomes noted in the above studies of service members and veterans, military service can also be a stressful occupation; accordingly, the frequency of developing stressrelated illnesses such as anxiety disorders, cardiovascular disease, chronic fatigue, and hypertension have been both hypothesized and shown to be higher among military veterans 
(e.g., Assari 2014, Bedi 2007, Coughlin 2011, Kang 2003). Veterans are also more likely to exhibit substance abuse (e.g., Blosnich 2010, NIDA 2013, Schumm 2012).

At its most current estimate, the VA approximates the number of U.S military veterans at 22 million individuals - just under 7\% of the population (VA 2014). This numerical minority of the national population is further stratified along categories of race and sex, with only $18 \%$ of the veteran population being racial minorities and only $9 \%$ being women. As of 2014, the number of gay and lesbian veterans being provided health care by the VA is estimated at approximately 1 million (Shipherd 2014). This number does not represent an accurate estimate of the number of LGBT veterans in the United States - only those who identify themselves to and receive health care services from the VA. This caveat is an important distinction, because research in the area of veterans' health has found great reluctance among veterans to disclose their gender identity or sexual orientation to the VA (e.g., Moradi 2009, Sherman 2014). It is entirely possible, and in fact quite likely, that this number is underreported (Gates 2004).

Though lacking a precise estimate of their numbers, we can assume that GLB veterans are a numerical minority within the population of U.S. military veterans, and we know that GLB individuals are a subordinate group in both the general population and within the populations of active duty military service members and veterans. With this point established, the current study considers sexual minority status — here defined as nonstraight sexual orientation - to be a status of subordinate minority similar to racial minority status and sex. It is reasonable to assume, as past literature has shown (e.g., Marx 1848, Wirth 1941, Crenshaw 1989, Browne 2003, Acker 2006, Pascoe 2009), that members of subordinate minorities may encounter disparities in their experiences when compared to 
members of dominant groups. In this paper, I investigate the health-related effects of four minority statuses — racial minority status, sex, sexual minority status, and veteran status — in terms of intersectionality theory and minority stress.

\section{Minority Stress}

The minority stress model has emerged recently in studies of racial minorities and sexual minorities by several authors spanning multiple disciplines from public health and medicine to psychology and sociology. Studies over the past 30 years have shown that minority statuses are correlated with an increased exposure to negative distal stressors such as discrimination, prejudice, and rejection (Clark 1999; Farrell 1988; Faulkner 1998; Feagin 1991; Herek 1992, 1999; Landrine 1996; Mays 2001; Meyer 2003; Thompson 1996; Williams 1999, 2003); with an increased frequency of negative proximal stressors such as anxiety, depression, identity strain, internalized stigma, rejection sensitivity, rumination, and social vigilance (Dohrenwend 2000; Goffman 1963; Hatzenbuehler 2009; Meyer 2003; Nolen-Hoeksema 2008, 2010; Pachankis 2007, 2008); and, that both types of stressors contribute to increased frequencies of negative or poor health outcomes (Cochran 2000b, 2000c; Gilman 2001; Goodman 2000; Herek 1999; Jackson 1996; Lick 2013; Mays 2001, 2002; Meyer 1995, 2003; Russel 2001; Williams 1997, 1999, 2003; Williamson 2000), increases in behavioral risk factors (Bennett 2005; Burgard 2005, Cochran 2000a; Gilman 2001; Goodman 2000; Landrine 1996; Krieger 1990; McKirnan 1988; Meyer 2003; Williams 1999, 2003), and victimization (Balsam 2005; Garnets 1990; Herek 1992, 1999). Unlike other stressors one may encounter in life, those related to one's minority status tend to be both chronic and unavoidable: one cannot simply stop being Black, or escape worry that one will not be taken seriously because she is a woman, or avoid fear of 
ridicule or victimization due to sexual orientation (Dohrenwend 2000). These chronic, mental stressors contribute to a variety of both physiological and mental health conditions among the stigmatized minority group, and a greater frequency of behavioral risk factors as negative coping behaviors (Gilman 2001, Burgard 2005, Moradi 2009).

As minority stress has been investigated among the groups of interest to the present study, I expect my findings to follow the predictions of established literature. For a detailed meta-analysis of minority stress studies, see Pascoe (2009). In the present study, I apply minority stress to an examination of veterans' health. I investigate disparity in self-reported health between male and female veterans, between white and non-white veterans, between straight and GLB veterans, and between veterans and non-veterans. I compare self-reported health for each combination of minority and non-minority statuses.

\section{Intersectionality}

Intersectionality is also a relatively new concept in social science literature. The term was introduced to the lexicon by Kimberle Crenshaw (1989) and further articulated by Patricia Hill Collins (1990), both in regards to the description and experience of Black feminism. In its initial use, the term referred to the experiences of Black women, who were hypothesized and observed to be more severely subordinated as a group with multiple disadvantaged statuses than were either Black people or women when considered alone. McCall (2005) describes this phenomenon as intercategorical complexity involving "relationships of inequality among already constructed social groups," and that these relationships exist "within and across analytical categories". The primary claim of the intersectionality framework is that multiple minority statuses — when considered together, in groups or individuals who with multiple disadvantaged statuses — are more likely to 
result in negative outcomes than the combined likelihoods of individual minority statuses - considered alone, in groups or individuals with single disadvantaged statuses suggests via simple arithmetic (Bowleg 2008, 2013). Since the introduction of intersectionality as a theoretical framework, the categories examined have grown beyond just the foundational intersection of race and sex. Cho (2013) recently observed that the intersectional approach has been applied to analyses of such social categories as gender, nationality, sexual orientation, and social class. Prior research in the area of veterans' health care has found that veterans with multiple minority statuses tend to exhibit disproportionately more negative health outcomes than their peers (e.g., Shipherd 2012, Blosnich 2013a, Blosnich 2013b, Mattocks 2013, Simpson 2013, Sherman 2014). These findings are in accordance with studies conducted among the general population, and reflect the concept of a "matrix of oppression" theorized by Collins (1990). The current study considers the intersection of racial minority status, sex, and sexual minority status on the health outcomes and risk factors of U.S. military veterans. I investigate intersectionality effects among and between combinations of the four minority statuses identified above, with the assumption that individuals with multiple disadvantaged statuses tend to fare worse than those with single disadvantaged statuses or no disadvantaged statuses.

\section{Research Question}

I have identified that racial minority status, female sex, sexual minority status, and veteran status all constitute disadvantaged minority statuses. The current study seeks to explore the effects of these disadvantaged statuses:

RQ: What are the effects of racial and sexual minority statuses on veterans' health? 
Guided by intersectionality theory and the minority stress model, I approach this study with the presumptions that minority statuses generally tend to result in detrimental effects and that those individuals with multiple disadvantaged statuses tend to fare worse than those with single or no disadvantaged statuses. As such, I arrive at the following predictions: 1: Minority statuses negatively influence veterans' health outcomes and risk factors. 2: Multiple minority statuses result in disproportionately negative health outcomes. Each minority status is predicted to exert main effects on dependent variables; moreover, each is predicted to contribute negatively to interaction terms. In this study, I investigate whether these predictions are true in a national, random sample which includes a subsample of 35,153 military veterans. 


\section{H A P T E R 3: METHODS}

The current study will conduct secondary data analysis using the 2014 and 2015 BRFSS questionnaire data. This dataset has been chosen primarily for its recency, size, and relevance to my research question. Every year since 1993, the BRFSS has been administered nationwide by the U.S. Department of Health and Human Services (HHS), Centers for Disease Control and Prevention (CDC) with the help of support drawn from relevant government offices and private firms in each state. The BRFSS consists of three elements: (1) a mandatory core questionnaire, which is administered uniformly in every state and to all participants; (2) several optional questionnaire modules that states may elect to include or exclude in each year, which are then administered uniformly in every state which elects to include them; (3) individual questions or questionnaire modules which states may elect to create and include with the uniform BRFSS material. Data from the first and second elements are reported to the $\mathrm{CDC}$, maintained as part of the public domain, and are freely available for public use on the CDC website. Data from the third element are not reported to the $\mathrm{CDC}$, are maintained by individual states, and may be available to the public freely, upon request, or for a fee. The BRFSS is conducted via random-digit dialing to cell phones and landline phones by trained interviewers. A detailed description of survey design and a full codebook of survey questions and responses is available from the CDC website.

Due to the modular nature of the BRFSS, not all questions are asked of all participants. Previous studies (e.g., Blosnich 2013b) have used data from the third element to acquire sample sizes large enough for analysis in situations where the core questionnaire and/or optional modules did not include specific questions of interest. While this method 
can result in larger sample sizes especially for sensitive areas of research, it also introduces the possibility of sampling biases due to the variation of question wording; e.g., Blosnich (2013b) noted that the state-added questions in the 2010 BRFSS included three distinct variations of the same question about sexual orientation. In the present study, I avoid this complication by using only data drawn from the first and second elements of the 2014 and 2015 BRFSS. Fortunately, the 2014 and 2015 BRFSS featured a sexual orientation and gender identity module which 20 states included in 2014 and 22 states included in 2015. States which included the module in 2014 were: Delaware, Hawaii, Idaho, Indiana, Iowa, Kansas, Kentucky, Louisiana, Maryland, Minnesota, Montana, Nevada, New York, Ohio, Pennsylvania, Vermont, Virginia, Wisconsin, Wyoming, and the U.S. territory Guam; states which included the module in 2015 were: Colorado, Connecticut, Delaware, Georgia, Hawaii, Idaho, Illinois, Indiana, Iowa, Kansas, Maryland, Massachusetts, Minnesota, Missouri, Nevada, New York, Ohio, Pennsylvania, Texas, Virginia, West Virginia, and Wisconsin. The resulting subsample of 910 sexual minority veterans is the largest such subsample of this population available for analysis, and should allow meaningful conclusions to be drawn.

The 2014 BRFSS annual survey data was released in September 2015 and accessed on 15 November 2015. The 2015 BRFSS annual survey data was released in September 2016 and accessed on 1 November 2016. Combined, the 2014 and 2015 BRFSS datasets have a total of 906,120 observations. Data analysis and manipulation was conducted using the STATA/IC v14.0 software package available from StataCorp. 


\section{Independent Variables: Minority Statuses}

I consider four independent variables for analysis: racial minority status, sex, sexual minority status, and veteran status. Each of these variables represents a status of either numerical or subordinate minority in the general population, and often both in the veteran population. Each variable is drawn from the 2014 and 2015 BRFSS datasets. From the codebook, each is verified to have the same question and response categories between years, and each has been manipulated to remove unnecessary data; for example, most questions on the BRFSS questionnaire include an option for "Don't Know," or missing responses which are not useful for the study. These data are routinely excluded from the analysis sample as part of data cleaning and preparation. In several cases, I also dropped extraneous responses which did not directly concern my research questions, and in one case I combined relevant responses. All data manipulations are described below.

First, the 2014 and 2015 datasets were combined and all 14,357 observations from Iowa were dropped. Iowa used the module for sexual orientation with a different weighting control, which would have interfered with analysis. Excluding Iowa did not meaningfully affect the dataset: no observations were dropped from the smallest subsample of interest, and fewer than ten from the two next-smallest subsamples. The combined dataset now has 891,763 observations.

Racial minority status is measured by modifying a BRFSS constructed variable which divides respondents into "Non-Hispanic White" or "Non-White or Hispanic". For this study, I dropped 15,148 responses of "Don't know," "Not sure," or "Refused," and 94 missing values from the combined dataset. The variable is recoded as dichotomously, with 
$0=$ "White" and $1=$ "Non-White" for racial minorities. The combined dataset now has 876,521 observations.

I recoded the variable for respondent sex. It was already dichotomous, and the codebook did not record missing data; however, I changed its values, from 1 and 2, to $0=$ "Male" and 1 = "Female".

Sexual minority status is measured by constructing a new, dichotomous variable based on the BRFSS variable for sexual orientation and gender identity. For this study, I dropped 2,794 responses of "Don't know/Not Sure," 4,700 "Refused," and 568,408 missing values from the combined dataset. Three categories from the parent variable are then combined: 4,035 responses of "Lesbian or gay," 4,100 "Bisexual," and 991 "Other" are merged into a new category, "Sexual Minority". The category "Straight" remains. A new, dichotomous variable is created with $0=$ "Straight" and $1=$ "Sexual Minority". The combined dataset now has 300,670 observations.

Veteran status is measured by constructing a new, dichotomous variable based on the BRFSS variable for veteran status. For this study, I dropped 63 responses of "Don't know/Not Sure," 109 "Refused," and 1 "Not asked or Missing” from the combined dataset. A new, dichotomous variable was created with the remaining categories, "Yes" and "No," recoded as $0=$ "Non-Veteran" and $1=$ "Veteran". The combined dataset now has 300,495 observations.

\section{Dependent Variable: Self-Reported Health}

The dependent variable self-reported health is measured on the 2014 and 2015 BRFSS survey instruments as “General Health". General health was reported on a 5-point Likert scale ranging from 1, being "Excellent," to 5, being "Poor". For this study, I dropped 
450 responses of "Don't know/Not Sure," 418 "Refused," and 2 "Not asked or Missing" from the combined dataset. The variable was then recoded such that $1=$ "Poor," $2=$ "Fair," 3 = "Good," 4 = "Very Good," 5 = "Excellent". The combined dataset now has 299,625 observations.

\section{Controls and Weighting}

Of considerable importance to this study is that results of analysis be representative of a larger population than the sample of analysis. To this end, I include three demographic variables available in the 2014 and 2015 BRFSS dataset as control variables: age, level of education, and level of income. Additionally, BRFSS documentation provides a weighting variable for use in data analysis which is not described but is included with all models.

Age is measured by modifying a constructed BRFSS variable which divides respondents into thirteen 5-year age groups ranging from "18-25" (one of two exceptions to 5-year age groups) to " 80 or older" (the other exception). For this study, I dropped 2,426 responses of "Don't Know/Refused/Missing" from the combined dataset. The remaining categories are left as they are. The combined dataset now has 297,199 observations.

Education is measured by modifying a constructed BRFSS variable which divides respondents into six levels of education. For this study, I dropped 493 responses of "Don't Know/Refused/Missing" from the combined dataset. The remaining categories are left as they are, coded such at $1=$ "Never attended school or only kindergarten," reported here as "None or Kindergarten," $2=$ "Grades 1 through 8 (Elementary)," reported here as "Elementary," 3 = "Grades 9 through 11 (Some high school)," reported here as "Some high school," 4 = "Grade 12 or GED (High school graduate)," reported here as "High School Graduate," $5=$ "College 1 year to 3 years (Some college or technical school)," reported 
here as "Some College," $6=$ "College 4 years or more (College graduate)," reported here as "College Graduate". The combined dataset now has 296,706 observations.

Income is measured by modifying a constructed BRFSS variable which divides respondents into eight levels of income. For this study, I dropped 19,652 responses of "Don't know/Not sure," 19,980 "Refused," and 1 "Not asked or Missing" from the combined dataset. The remaining categories are left as they are, coded such that $1=$ "Less than $\$ 10,000$," also reported here as $<\$ 10,000 ; 2=$ "Less than $\$ 15,000(\$ 10,000$ to less than $\$ 15,000)$," also reported here as $<\$ 15,000 ; 3=$ "Less than $\$ 20,000(\$ 15,000$ to less than $\$ 20,000)$," also reported here as $<\$ 20,000 ; 4=$ "Less than $\$ 25,000$ ( $\$ 20,000$ to less than $\$ 25,000)$," also reported here as $<\$ 25,000 ; 5=$ "Less than $\$ 35,000$ ( $\$ 25,000$ to less than $\$ 35,000$ )," also reported here as $<\$ 35,000 ; 6=$ "Less than $\$ 50,000$ (\$35,000 to less than $\$ 50,000)$," also reported here as $<\$ 50,000 ; 7=$ "Less than $\$ 75,000$ (\$50,000 to less than $\$ 75,000)$," also reported here as $<\$ 75,000 ; 8=" \$ 75,000$ or more," also reported here as $>\$ 75,000$. The combined dataset now has 257,073 observations.

\section{Analysis}

Analysis of the above variables consists of two primary parts: descriptive statistics, and inferential statistics. The dataset is described by the frequency and percentage of each independent and control variable, and by the frequencies of each possible combination of the four independent variables. Inferential statistics include analysis of linear and logit regression models and four-way interaction terms.

My theoretical framework leads me to expect lower self-reported health among all respondents with disadvantaged minority statuses, and disproportionately lower selfreported health among those with multiple disadvantaged statuses. 


\section{H A P T E R 4: RESULTS}

In the total sample of analysis, 146,008 respondents $(56.80 \%)$ identified as female, 49,957 (19.43\%) identified as racial minorities, 7,930 (3.08\%) as sexual minorities, and 35,163 (13.68\%) as veterans. Table 1, "Summary Statistics," displays these frequencies, and the frequencies of control variable categories, in the sample of analysis. Distributions of control variable categories are not normal, and are right-skewed $(\mathrm{p}<0.0001)$. Described in Chapter 3, control variables were recorded as categorical values. I conducted likelihood ratio tests to determine whether category scales were continuous "enough" to be treated as such in regression models. They were not, which informed choice of models.

Compared to the national average, the sample of analysis reports lower percentages of racial minorities and higher percentages of veterans (Census 2010). Whereas $63.7 \%$ of Census respondents identified as "Non-Hispanic White," that number is $80.57 \%$ in the sample of analysis; and, whereas $50.8 \%$ of Census respondents identified as female, that number is $56.80 \%$ in the sample of analysis. The sample of analysis also contains larger percentages than the estimated national averages of sexual minorities (Gates 2007) and veterans (Census 2013). Whereas sexual minorities constitute less than $2 \%$ of the national population, they constitute $3.08 \%$ of the sample of analysis; and, whereas less than $10 \%$ of the national population are veterans, $13.68 \%$ of the analysis sample are veterans.

Table 2, "Two-Way Intersection Frequencies with Row Percentages" displays all combinations of two independent variables. The most frequent two-way intersection of independent variables in the sample of analysis is "Straight $\times$ White," numbering 201,221 respondents (78.27\%), which is $80.76 \%$ of straight respondents and $97.15 \%$ of whites. The least frequent two-way intersection in the analysis sample is "Sexual Minority $\times$ Veteran," 
numbering 910 respondents $(0.35 \%)$, which is $11.47 \%$ of sexual minority respondents and $2.58 \%$ of veterans. Table 3, "Three-Way Intersection Frequencies," displays combinations of three independent variables. The most frequent three-way intersection of independent variables is "Straight $\times$ White $\times$ Non-Veteran," numbering 177,529 respondents $(69.05 \%)$, which is $71.25 \%$ of straight respondents, $85.71 \%$ of whites, and $80.00 \%$ of non-veterans. The least frequent three-way intersection of independent variables is "Sexual Minority $\times$ Non-White $\times$ Veteran," numbering 192 respondents $(0.07 \%)$, which is $2.42 \%$ of sexual minority respondents, $0.38 \%$ of racial minorities, and $0.54 \%$ of veterans. Table 4 , "FourWay Intersection Frequencies with Row Percentages," displays all combinations of all four independent variables. The most frequent intersection of all four independent variables in the sample of analysis is "Straight $\times$ White $\times$ Female $\times$ Non-Veteran," numbering 111,662 respondents (43.44\%), which is $44.81 \%$ of straight respondents, $53.91 \%$ of whites, $76.47 \%$ of females, and $50.31 \%$ of non-veterans. The least frequent intersection of four independent variables in the sample of analysis is "Sexual Minority $\times$ Non-White $\times$ Female $\times$ Veteran," numbering 62 respondents $(0.02 \%)$, which is $0.78 \%$ of sexual minority respondents, $0.12 \%$ of racial minorities, $0.04 \%$ of females, and $0.17 \%$ of veterans.

Six statistical models were investigated, and are grouped into two triads consisting of the same regression models run respectively with and without the presence of categorical control variables for age, education, and income. These six models are numbered " 1 ," " 2 ," and "3," each accompanied by a letter variant, either "A" or "B," and referenced as such both in this manuscript and on attached tables. "A" models are those without control variables, the results of which are displayed on Table 5, "Models Without Control Variables," and "B" models are those with categorical control variables, which are 
displayed in Table 6, "Models with Categorical Control Variables." Models without control variables are included in this paper to illustrate unexpected findings which would have been overlooked had they not been included in the initial inquiry.

In each table, three models describe four-way interactions of independent variables. Model 1 is a linear regression of self-reported health, a continuous variable with responses coded on a 5 -point scale as $1=$ Poor, $2=$ Fair, $3=$ Good, $4=$ Very Good, $5=$ Excellent . Ferraro $(1980,1999)$ has demonstrated the utility and veracity of self-reported health as an indicator of actual health; moreover, Lissitz \& Green (1975) have argued that 5-point scales are sufficiently reliable for analysis, and that additional scale points do not meaningfully increase reliability. Linear regression models are chosen for their ease of interpretation and familiarity among academic audiences. Model 2 is an ordinal logit regression of selfreported health on the same 5-point scale used in Model 1. Model 3 is a logit regression of self-reported health as a calculated, dichotomous variable coded such that a response of "Good" or better on the original 5-point scale = 1. "Good" or better was chosen as the cutoff point for the dichotomous variable at the suggestion of my major professor, and this decision is consistent with several studies in health literature advocating the utility of dichotomizing 5-point self-reported health scales (e.g., Bourne 2009, Dominick 2004, Reichmann 2009). The logit model is included specifically for the created, dichotomous variable to address concerns that linear and ordinal models on a 5-point variable may be lacking in sufficient reliability for analysis. Raw data and outputs for all models and tests are available upon request in Excel, Stata, and plain text formats. 
Table 5 displays three models without control variables. Model 1A displays three statistically significant two-way interactions: "Female $\times$ Racial Minority," "Female $\times$ Veteran," and "Racial Minority $\times$ Veteran".

The interaction between Female sex and racial minority status is statistically significant, predicting that Non-White females on average report their health as 0.0974 points lower on a 5-point scale $(\mathrm{p}<0.0001)$. Figure 1 , "Female $\times$ Racial," plots the interaction term, with the solid line marking the average of White and Non-White males and females. On average, females have higher-self reported health than males, Whites have higher self-reported health than non-Whites, and female Whites have the highest selfreported health. Non-White males have worse self-reported health than White males or the average of males and females, and non-White females have worse self-reported health than their non-White male peers. Moreover, the self-reported health of non-White females is so much lower than that of their White peers that the Female sex on average adopts a negative coefficient in linear regression with self-reported health. Although substantively meager, this finding is consistent with predictions - and with assumptions of Black feminism and intersectionality that having multiple minority statuses is disproportionately disadvantageous.

The interaction between veteran status and Female sex is statistically significant, predicting that female veterans on average report their health as 0.2473 points higher on a 5-point scale $(\mathrm{p}<0.0001)$ than non-Veteran females. Figure 2, "Veteran $\times$ Female," plots the interaction term, with the solid line marking the average of male and female Veterans and Non-Veterans. On average, veterans have lower self-reported health than non-veterans, but with relatively large variance. As noted above, without control variables the self- 
reported health of females is lower than their male peers on average, and this remains true among the large subsample of non-veterans: non-veteran females report worse health than their male peers. By contrast, female veterans have higher self-reported health than nonveteran females, and higher than non-veteran males and male veterans. This finding is not consistent with predictions.

The interaction between veteran status and racial minority status is statistically significant, predicting that racial minority veterans on average report their health as 0.1547 points higher on a 5-point scale $(\mathrm{p}<0.001)$ than non-Veteran racial minorities. Figure 3 , "Veteran $\times$ Racial," plots the interaction term, with the solid line marking the average of White and Non-White veterans and von-veterans. On average, veterans have lower selfreported health than non-veterans, and Whites have higher self-reported health than nonWhites. White veterans have lower self-reported health than White non-veterans, but NonWhite veterans have higher self-reported health than Non-White non-veterans. This finding is not consistent with predictions.

In Model 1A, veteran status does not appear to behave as a disadvantaged/minority status in interaction terms. Though only those described above are statistically significant, it is worth noting that every interaction term involving veteran status yields unexpectedly high coefficients - and many of them are positive. This suggests that veteran status may itself function as a control variable, or otherwise exert an equalizing or mitigating effect on self-reported health. That veteran status itself remains negatively associated with selfreported health raises questions and warrants further inquiry.

In Model 1A, no interaction terms involving sexual minority status are statistically significant; however, sexual minority status does predict a statistically significant, negative 
association with self-reported health which matches theoretical predictions. Models $2 \mathrm{~A}$ and 3A reproduce the same, expected directionality of effects among the independent variables upon self-reported health and the same, unexpected directionality of effects among the statistically significant interaction terms. Discrepancies between these models justify the redundancy of their inclusion: for example, note that in Model 2A the effect of female sex on self-reported health is not statistically significant, and in Model 3A the interaction between Female sex and racial minority status is not statistically significant — had either of these models been excluded, then the discrepancies described here might have been inaccurately assumed to be meaningful rather than merely anomalies. As the corresponding values remain statistically significant in the other models tested, the discrepancies are rightly disregarded as anomalous and focus remains on the interaction effects between veteran status and both Female sex and racial minority status — which remain extremely statistically significant. In fact, under logistic models $2 \mathrm{~A}$ and $3 \mathrm{~A}$, higher coefficients for those interaction effects suggest that the mitigating value of veteran status is even more pronounced! Here, diverse models yielding the same general finding lends weight to its reliability. Discrepancies and pitfalls are not unexpected, as all models on Table 5 are understandably limited by the absence of control variables. That limitation is reflected in the abysmally low $\mathrm{R}^{2}$ value 0.0116 for Model $1 \mathrm{~A}$, predicting that these models account for only $1.16 \%$ of the observed effects.

Table 6 shows three models with categorical control variables. Several differences are immediately apparent in Model 1B: first, all interaction terms except for "Female $\times$ Racial" lose their statistical significance, and even the negative, statistically non-significant coefficients are quite low; second, the directionality of effect Female sex has on self- 
reported health is reversed to become positive; and, racial minority status no longer has a statistically significant effect on self-reported health. By contrast, age and income are each extremely statistically significant $(\mathrm{p}<0.001)$ in all but one categorical bracket; moreover, coefficients for these variables are quite large, suggesting they are also practically significant. Age is negatively associated with self-reported health in all non-reference category brackets, with coefficients ranging from -0.1508 in the $26-30$ age category to 0.6682 in the $80+$ bracket. By contrast, income is positively associated with self-reported health in all non-reference brackets, with statistically significant coefficients ranging from 0.2038 at income values below $\$ 20,000$ but above $\$ 15,000$ to 0.8686 - representing nearly a full, 1-point increase on the 5-point scale — at income values of $\$ 75,000$ or higher. These findings are consistent with predictions.

Model 2B meaningfully diverts from Models $1 \mathrm{~B}$ and 2A only with the statistical significance of the interaction term "Female $\times$ Sexual," predicting that sexual minority females on average report their health 0.2108 points lower on a 5 -point scale $(\mathrm{p}<0.05)$. This finding is consistent with predictions, and with statistically non-significant values found in other models. Model 3B meaningfully diverts from Models 1B only with the addition of a statistically significant coefficient $(0.1753 ; \mathrm{p}<0.001)$ for income values below $\$ 15,000$ but above $\$ 10,000$. This makes Model $3 \mathrm{~A}$ the only model in which every non-reference income category is statistically significant. 


\section{H A P T E R 5: CONCLUSIONS AND DISCUSSION}

Analysis yielded mixed results. Independent variables were statistically significant to various degrees in all models; however, most interaction terms were not. Further, neither the four-way interaction of all independent variables, which was the interaction of primary interest for this study, nor any three-way interactions were statistically significant. Lack of statistical significance in three- and four-way interaction terms is contrasted by unexpected, statistically significant interactions involving veteran status. The interactions "Veteran $\times$ Female" and "Veteran $\times$ Racial Minority" yield statistically significant positive effects on self-reported health across all three models lacking control variables (see Table 5). In each of those models, racial minority status is statistically significant and negatively associated with self-reported health, and in two models the female sex is statistically significant and negatively associated with self-reported health. That a positive association with selfreported health comes from the interaction of variables that each hold negative associations is surprising. In fact, every interaction involving veteran status without control variables yields higher coefficients than expected — and many have positive associations, despite the negative associations of their component variables. Simply, the interaction effect of veteran status appears to mitigate the negative effects of other minority statuses. This effect is muddled by the absence of both control variables and the lack of statistical significance in all but the two interaction terms identified.

In models with control variables, female sex behaved as expected in statistically significant interaction terms. The interaction "Female $\times$ Racial Minority" yielded statistically significant negative effects $(p<0.001)$ on self-reported health across all three control models. This is perhaps the single finding most consistent with intersectionality 
assumptions, and the interaction term with which models show most consistent agreement. Less significant was the "Female $\times$ Sexual Minority" interaction term, which was observed to be statistically significant $(p<0.05)$ only in ordinal regression (see Table 6, Model 2B).

Beyond interaction terms, results mostly coincided with expected outcomes. Across all models, racial minority, sexual minority, and veteran status were negatively associated with self-reported health. Sexual minority status yielded statistically significant results in all models at the level $p<0.01$ and often at the level $p<0.001$; further, the negative effect of sexual minority status on self-reported health was not diminished by the presence of control variables. In models with control variables, female sex, racial minority, and veteran status all displayed higher coefficients suggestive of the equalizing and mitigating effects of those control variables; however, the coefficients for sexual minority status slightly decreased. This finding suggests the stressors faced by sexual minorities are especially strong and/or are not diminished by advantages in education or income.

The negative effect of racial minority status on self-reported health is most strongly affected by the inclusion of control variables, so much so that statistical significance is lost. This finding suggests Non-Whites and Whites of similar demographic backgrounds are on relatively even footing.

\section{Limitations and Future Research}

The dataset from which the sample of analysis is drawn presents the first and largest limitation of this study. As the survey item indicating sexual orientation was present only in an optional BRFSS module, data is available only for respondents from states that elected to include it in a given year; therefore, potential observations from more than half of BRFSS respondents and from two-thirds of the states for each year were excluded from 
the analytic sample. The dropped observations not only represent the unrealized potential for stronger analysis, but also are so widespread as to potentially raise concerns with representativeness of conclusions drawn from this analysis. The optional BRFSS module for sexual orientation is a recent innovation; future research may benefit from its inclusion by more states in their yearly administration of the BRFSS, or ideally from its assimilation into the BRFSS core questionnaire so that every respondent is asked the question.

Limitations also arise from the variables chosen for regression models — or, more accurately, from those not chosen. While demonstrably better than none, including only three control variables does not fully account for conceivable permutations of effects on the dependent variable by the independent variables. This incompleteness is evident in the low $\mathrm{R}^{2}$ value of linear regression, reflecting that models explain only $16 \%$ of observed effects (Table 5, Model 2A). Future research will benefit from more control variables, such that models explain more of the observed effect.

Additionally, the current study has only a single dependent variable. The validity of selfreported health as an indicator is well-established in the literature (e.g., Haddock 2005, Miilunpalo 1997), but as the only indicator of health outcomes it lacks nuance and specificity. It is conceivable that racial minorities, sexual minorities, and/or veterans may disproportionately suffer from negative outcomes in specific areas of health that a general measure of overall health does not sufficiently convey. Moreover, self-reported health does not differentiate between physical and mental health, illness or injury, and so on. Future research would benefit from inquiry into additional health indicators and specific outcome indicators for greater reliability and specificity. 


\section{Future Contributions}

This study contributes a hitherto undocumented mitigating effect of veteran status on self-reported health among individuals with multiple disadvantaged/minority statuses. Though this finding is contrary to the theoretical framework used in the study, one might speculate as to its cause. Especially given its appearance only in models without control variables, it stands to reason that the most disadvantaged individuals experience the effect most strongly exactly because they are so disadvantaged. Military service, for which the veteran status is a precursor, affords minority individuals who are poor and/or uneducated access to goods and services they might otherwise be unable to obtain, such as nutritious meals, stable housing, medical and dental care, legal representation, and so on. This logic also explains why the mitigating effect diminishes or disappears in models with control variables: while the perks and prestige of military service are comparative godsend to the severely disadvantaged, individuals with average or above-average income and education gain far less utility from them relative to their own prospects elsewhere.

That this almost "common sense" mitigating effect of veteran status is novel, and was revealed unexpectedly, speaks to the gap in extant literature of minority veterans and veterans' health which this paper seeks to help fill. Further research is needed both to probe deeper into understanding this effect and to broaden the scope of the literature in search of other as yet unrevealed novelties. 


\section{H A P T E R 6: FIGURES AND TABLES}

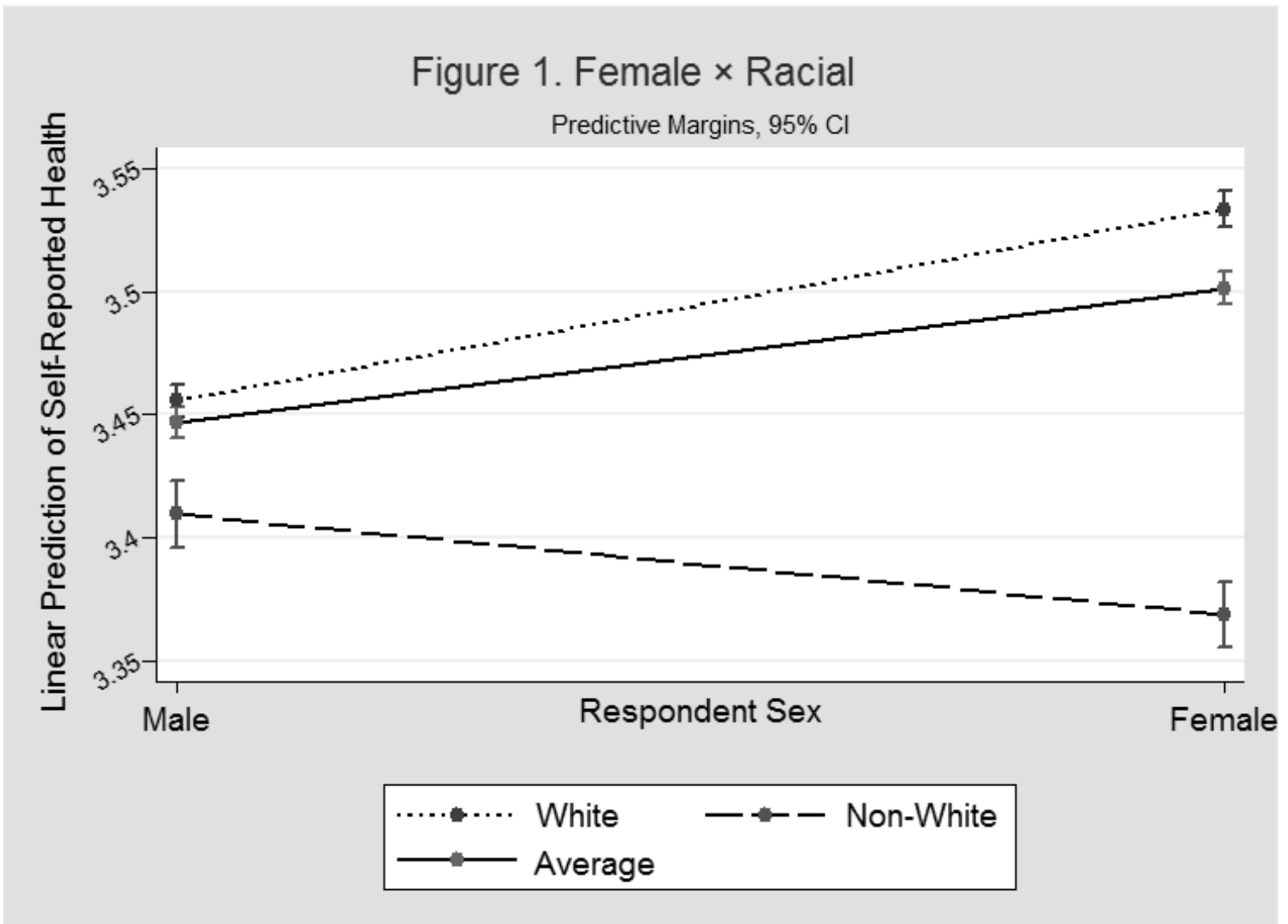




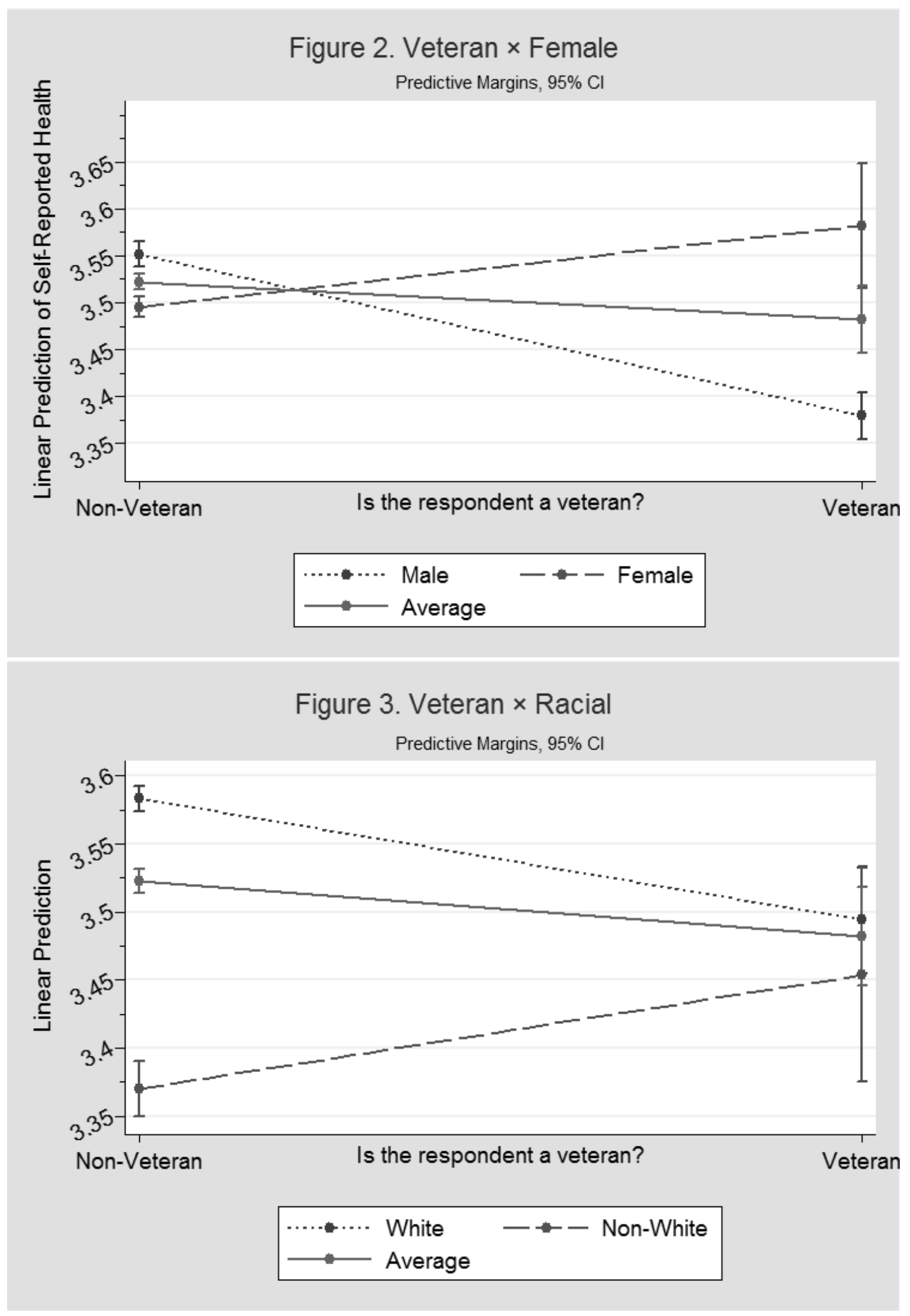


Table 1. Summary Statistics

\begin{tabular}{|c|c|c|}
\hline Demographic Variables & Frequency & Percent \\
\hline \multicolumn{3}{|l|}{ Respondent Sex } \\
\hline Male & 111,065 & 43.20 \\
\hline Female & 146,008 & 56.80 \\
\hline \multicolumn{3}{|l|}{ Racial Minority Status } \\
\hline White & 207,116 & 80.57 \\
\hline Non-White & 49,957 & 19.43 \\
\hline \multicolumn{3}{|l|}{ Sexual Minority Status } \\
\hline Straight & 249,143 & 96.92 \\
\hline Sexual Minority & 7,930 & 3.08 \\
\hline \multicolumn{3}{|l|}{ Veteran Status } \\
\hline Non-Veteran & 221,910 & 86.32 \\
\hline Veteran & 35,163 & 13.68 \\
\hline \multicolumn{3}{|l|}{ Age Group } \\
\hline $18-25$ & 11,151 & 4.34 \\
\hline $26-30$ & 10,390 & 4.04 \\
\hline $31-35$ & 13,256 & 5.16 \\
\hline $36-40$ & 14,751 & 5.74 \\
\hline $41-45$ & 16,720 & 6.50 \\
\hline $46-50$ & 19,719 & 7.67 \\
\hline $51-55$ & 26,003 & 10.12 \\
\hline $56-60$ & 29,750 & 11.57 \\
\hline $61-65$ & 31,398 & 12.21 \\
\hline $66-70$ & 29,214 & 11.36 \\
\hline $71-75$ & 21,941 & 8.53 \\
\hline $76-80$ & 15,062 & 5.86 \\
\hline $80+$ & 17,718 & 6.89 \\
\hline \multicolumn{3}{|l|}{ Education Level } \\
\hline None or Kindergarten & 192 & 0.07 \\
\hline Elementary & 3,968 & 1.54 \\
\hline Some High School & 11,369 & 4.42 \\
\hline High School Graduate & 70,744 & 27.52 \\
\hline Some College & 70,449 & 27.40 \\
\hline College Graduate & 100,531 & 39.04 \\
\hline \multicolumn{3}{|l|}{ Income Bracket } \\
\hline Less than $\$ 10,000$ & 10,920 & 4.25 \\
\hline Less than $\$ 15,000$ & 12,641 & 4.92 \\
\hline Less than $\$ 20,000$ & 17,967 & 6.99 \\
\hline Less than $\$ 25,000$ & 22,994 & 8.94 \\
\hline Less than $\$ 35,000$ & 28,320 & 11.02 \\
\hline Less than $\$ 50,000$ & 37,723 & 14.67 \\
\hline Less than $\$ 75,000$ & 42,606 & 16.57 \\
\hline$\$ 75,000$ or more & 83,902 & 32.64 \\
\hline
\end{tabular}


Table 2. Two-Way Intersection Frequencies with Row Percentages

\begin{tabular}{|c|c|c|c|}
\hline & & \multicolumn{2}{|c|}{ Respondent Sex } \\
\hline Racial Minority Status & & Male & Female \\
\hline & White & $\begin{array}{c}90,313 \\
(43.61 \%)\end{array}$ & $\begin{array}{l}116,803 \\
(56.39 \%)\end{array}$ \\
\hline & Non-White & $\begin{array}{c}20,752 \\
(41.54 \%)\end{array}$ & $\begin{array}{c}29,205 \\
(58.46 \%)\end{array}$ \\
\hline Sexual Minority Status & & Male & Female \\
\hline & Straight & $\begin{array}{l}107,341 \\
(43.08 \%)\end{array}$ & $\begin{array}{l}141,802 \\
(56.92 \%) \\
\end{array}$ \\
\hline & Minority & $\begin{array}{c}3,724 \\
(46.98 \%) \\
\end{array}$ & $\begin{array}{c}4,206 \\
(53.04 \%)\end{array}$ \\
\hline Veteran status & & Male & Female \\
\hline & Non-Veteran & $\begin{array}{c}79,037 \\
(35.62 \%)\end{array}$ & $\begin{array}{l}142,873 \\
(64.38 \%)\end{array}$ \\
\hline & Veteran & $\begin{array}{c}32,028 \\
(91.08 \%)\end{array}$ & $\begin{array}{c}3,135 \\
(8.92 \%)\end{array}$ \\
\hline
\end{tabular}

\begin{tabular}{|c|c|c|}
\hline & \multicolumn{2}{|c|}{ Sexual Minority } \\
\hline Racial Minority Status & Straight & Minority \\
\hline \multirow{2}{*}{ White } & $\begin{array}{c}201,221 \\
(97.15 \%)\end{array}$ & $\begin{array}{c}5,905 \\
(2.85 \%)\end{array}$ \\
\hline \multirow{2}{*}{ Non-White } & $\begin{array}{c}47,932 \\
(95.95 \%)\end{array}$ & $\begin{array}{c}2,025 \\
(4.05 \%)\end{array}$ \\
& Straight & Minority \\
\hline Veteran Status & 214,890 & 7,020 \\
& $(96.84 \%)$ & $(3.16 \%)$ \\
\hline \multirow{2}{*}{ Non-Veteran } & $\begin{array}{c}34,253 \\
(97.41 \%)\end{array}$ & $(2.59 \%)$ \\
\hline \multirow{2}{*}{ Veteran } & & \\
& &
\end{tabular}

\begin{tabular}{|c|c|c|}
\hline & \multicolumn{2}{|c|}{ Racial Minority } \\
\hline Veteran Status & White & Non-White \\
\hline \multirow{2}{*}{ Non-Veteran } & $\begin{array}{c}177,716 \\
(80.08 \%)\end{array}$ & $\begin{array}{c}44,194 \\
(19.92 \%)\end{array}$ \\
\hline \multirow{2}{*}{ Veteran } & 29,400 & 5,763 \\
& $(83.61 \%)$ & $(16.39 \%)$ \\
\hline
\end{tabular}


Table 3. Three-Way Intersection of Frequencies

\begin{tabular}{|r|l|r|r|r|}
\hline \multicolumn{2}{|c|}{} & \multicolumn{2}{|c|}{ Respondent Sex } & \\
\hline \multicolumn{2}{|c|}{ Sexual $\times$ Veteran } & Male & Female & \multicolumn{1}{c|}{ Total } \\
\hline \multirow{2}{*}{ Straight } & Non-Veteran & 76,030 & 138,860 & 214,890 \\
\cline { 2 - 5 } & Veteran & 31,311 & 2,942 & 34,253 \\
\hline \multirow{2}{*}{ Minority } & Non-Veteran & 3,007 & 4,013 & 7,020 \\
\cline { 2 - 5 } & Veteran & 717 & 193 & 910 \\
\hline \multirow{2}{*}{ Racial $\times$ Veteran } & Male & Female & Total \\
\hline \multirow{2}{*}{ White } & Non-Veteran & 63,137 & 114,579 & 177,716 \\
\cline { 2 - 5 } & Veteran & 27,176 & 2,224 & 29,400 \\
\hline \multirow{2}{*}{ Non-White } & Non-Veteran & 15,900 & 28,294 & 44,194 \\
\cline { 2 - 5 } & Veteran & 4,852 & 911 & 5,763 \\
\hline
\end{tabular}

\begin{tabular}{|r|l|r|r|r|}
\hline \multicolumn{2}{|l|}{} & \multicolumn{2}{|c|}{ Sexual Minority Status } & \multicolumn{1}{|c|}{ Total } \\
\hline \multicolumn{2}{|c|}{ Racial $\times$ Veteran } & Straight & Minority & \multicolumn{1}{|c|}{ Thite } \\
\cline { 2 - 5 } & Non-Veteran & 172,529 & 5,187 & 177,716 \\
\cline { 2 - 5 } & Veteran & 28,682 & 718 & 29,400 \\
\hline \multirow{2}{*}{ Non-White } & Non-Veteran & 42,361 & 1,833 & 44,194 \\
\cline { 2 - 5 } & Veteran & 5,571 & 192 & 5,763 \\
\hline
\end{tabular}

Table 4. Four-Way Intersection Frequencies with Row Percentages

\begin{tabular}{|r|c|c|c|}
\hline & Male & Female & Total \\
\hline White Straight Non-Veteran & $\begin{array}{c}60,867 \\
(35.28 \%)\end{array}$ & $\begin{array}{c}111,662 \\
(64.72 \%)\end{array}$ & 172,529 \\
\hline White Straight Veteran & $\begin{array}{c}26,589 \\
(92.70 \%)\end{array}$ & $\begin{array}{c}2,093 \\
(7.30 \%)\end{array}$ & 28,682 \\
\hline White Minority Non-Veteran & $\begin{array}{c}2,270 \\
(43.76 \%)\end{array}$ & $\begin{array}{c}2,917 \\
(56.24 \%)\end{array}$ & 5,187 \\
\hline White Minority Veteran & $\begin{array}{c}587 \\
(81.75 \%)\end{array}$ & $\begin{array}{c}131 \\
(18.25 \%)\end{array}$ & 718 \\
\hline Non-White Straight Veteran & $\begin{array}{c}15,722 \\
(84.76 \%)\end{array}$ & $\begin{array}{c}27,198 \\
(154.21 \%)\end{array}$ & 42,961 \\
\hline Non-White Minority Non-Veteran & $\begin{array}{r}737 \\
(40.21 \%)\end{array}$ & $\begin{array}{c}1,096 \\
(59.79 \%)\end{array}$ & 1,833 \\
\hline Non-White Minority Veteran & $\begin{array}{c}130 \\
(67.71 \%)\end{array}$ & $\begin{array}{r}62 \\
(32.29 \%)\end{array}$ & 192 \\
\hline
\end{tabular}


Table 5. Models Without Control Variables

\begin{tabular}{|c|c|c|c|}
\hline Regressor / Model & $(1 \mathrm{~A})$ & $(2 \mathrm{~A})$ & $(3 \mathrm{~A})$ \\
\hline \multicolumn{4}{|c|}{ Independent Variables } \\
\hline Sex $\quad($ female=1) & $\begin{array}{l}-0.0245 * \star \\
(0.0095)\end{array}$ & $\begin{array}{c}-0.0288 \\
(0.0164) \\
\end{array}$ & $\begin{array}{r}-0.1439 t \\
(0.0264)\end{array}$ \\
\hline Racial Minority & $\begin{array}{c}-0.1633 t \\
(0.0182)\end{array}$ & $\begin{array}{c}-0.2969 t \\
(0.0312)\end{array}$ & $\begin{array}{r}-0.3637 t \\
(0.0450)\end{array}$ \\
\hline Sexual Minority & $\begin{array}{l}-0.1215 * \star \\
(0.0405)\end{array}$ & $\begin{array}{c}-0.1886 * \star \\
(0.0673)\end{array}$ & $\begin{array}{r}-0.3397 t \\
(0.1036)\end{array}$ \\
\hline Veteran & $\begin{array}{c}-0.2150 \dagger \\
(0.0142)\end{array}$ & $\begin{array}{c}-0.3556 t \\
(0.0242)\end{array}$ & $\begin{array}{r}-0.4735 t \\
(0.0349)\end{array}$ \\
\hline
\end{tabular}

Interaction Terms

\begin{tabular}{|c|c|c|c|}
\hline Female $\times$ Racial & $\begin{array}{c}-0.0974 t \\
(0.0231)\end{array}$ & $\begin{array}{c}-0.1868 t \\
(0.0396)\end{array}$ & $\begin{array}{l}-0.0803 \\
(0.0556)\end{array}$ \\
\hline Female $\times$ Sexual & $\begin{array}{c}-0.0556 \\
(0.0554)\end{array}$ & $\begin{array}{l}-0.1040 \\
(0.0928)\end{array}$ & $\begin{array}{c}-0.0109 \\
(0.1376)\end{array}$ \\
\hline Racial $\times$ Sexual & $\begin{array}{c}0.0887 \\
(0.0788)\end{array}$ & $\begin{array}{c}0.1525 \\
(0.1396)\end{array}$ & $\begin{array}{c}0.1362 \\
(0.1794)\end{array}$ \\
\hline Female $\times$ Racial $\times$ Sexual & $\begin{array}{c}-0.1667 \\
(0.1051)\end{array}$ & $\begin{array}{c}-0.2993 \\
(0.1834)\end{array}$ & $\begin{array}{l}-0.2970 \\
(0.2404)\end{array}$ \\
\hline Female $\times$ Veteran & $\begin{array}{c}0.2473 t \\
(0.0418)\end{array}$ & $\begin{array}{c}0.4061 t \\
(0.0721)\end{array}$ & $\begin{array}{r}0.4849 t \\
(0.1220)\end{array}$ \\
\hline Racial $\times$ Veteran & $\begin{array}{c}0.1547 t \\
(0.0403)\end{array}$ & $\begin{array}{r}0.2725 t \\
(0.0696)\end{array}$ & $\begin{array}{r}0.2761 \dagger \\
(0.0868)\end{array}$ \\
\hline Female $\times$ Racial $\times$ Veteran & $\begin{array}{c}0.0329 \\
(0.0944)\end{array}$ & $\begin{array}{c}0.0715 \\
(0.1625)\end{array}$ & $\begin{array}{c}0.2304 \\
(0.2322)\end{array}$ \\
\hline Sexual $\times$ Veteran & $\begin{array}{c}-0.0931 \\
(0.0770)\end{array}$ & $\begin{array}{c}-0.1907 \\
(0.1302)\end{array}$ & $\begin{array}{c}0.0189 \\
(0.1914)\end{array}$ \\
\hline Female $\times$ Sexual $\times$ Veteran & $\begin{array}{c}0.1032 \\
(0.1963)\end{array}$ & $\begin{array}{c}0.2056 \\
(0.3604)\end{array}$ & $\begin{array}{c}-0.2179 \\
(0.4517)\end{array}$ \\
\hline Racial $\times$ Sexual $\times$ Veteran & $\begin{array}{c}0.0768 \\
(0.2180)\end{array}$ & $\begin{array}{c}0.1496 \\
(0.4014)\end{array}$ & $\begin{array}{c}-0.1049 \\
(0.4508)\end{array}$ \\
\hline Female $\times$ Racial $\times$ Sexual $\times$ Veteran & $\begin{array}{c}-0.0891 \\
(0.3233)\end{array}$ & $\begin{array}{c}-0.1857 \\
(0.5839)\end{array}$ & $\begin{array}{c}1.3895 \\
(0.7999)\end{array}$ \\
\hline
\end{tabular}

Summary Statistics

\begin{tabular}{|l|c|c|c|}
\hline$Y$-Intercept & $\begin{array}{c}3.6014 t \\
(0.0075)\end{array}$ & $\begin{array}{c}3.3088 t \\
(0.0225)\end{array}$ & $\begin{array}{r}1.8916 \dagger \\
(0.0217)\end{array}$ \\
\hline$R^{2}$ & 0.0116 & & \\
\hline
\end{tabular}


Table 6. Models with Categorical Control Variables

\begin{tabular}{|c|c|c|c|}
\hline Regressor / Model & (1B) & (2B) & $(3 \mathrm{~B})$ \\
\hline \multicolumn{4}{|c|}{ Independent Variables } \\
\hline Sex $($ female=1) & $\begin{array}{r}0.0639 t \\
(0.0089)\end{array}$ & $\begin{array}{r}0.1362 t \\
(0.0170)\end{array}$ & $\begin{array}{c}0.0719 * \\
(0.0285)\end{array}$ \\
\hline Racial Minority & $\begin{array}{c}-0.0139 \\
(0.0171)\end{array}$ & $\begin{array}{c}-0.0383 \\
(0.0321)\end{array}$ & $\begin{array}{c}-0.0084 \\
(0.0498)\end{array}$ \\
\hline Sexual Minority & $\begin{array}{c}-0.1318 t \\
(0.0400)\end{array}$ & $\begin{array}{c}-0.2146 * \star \\
(0.0716)\end{array}$ & $\begin{array}{r}-0.3867 t \\
(0.1197)\end{array}$ \\
\hline Veteran & $\begin{array}{c}-0.0491 \dagger \\
(0.0136)\end{array}$ & $\begin{array}{l}-0.0751 * \star \\
(0.0257)\end{array}$ & $\begin{array}{r}-0.2002 \dagger \\
(0.0380)\end{array}$ \\
\hline
\end{tabular}

Interaction Terms

\begin{tabular}{|c|c|c|c|}
\hline Female $\times$ Racial & $\begin{array}{c}-0.1364 t \\
(0.0216)\end{array}$ & $\begin{array}{c}-0.2778 t \\
(0.0404)\end{array}$ & $\begin{array}{c}-0.2128 t \\
(0.0608)\end{array}$ \\
\hline Female $\times$ Sexual & $\begin{array}{c}-0.1048 \\
(0.0547)\end{array}$ & $\begin{array}{c}-0.2108 * \\
(0.0981)\end{array}$ & $\begin{array}{c}-0.1787 \\
(0.1577)\end{array}$ \\
\hline Racial $\times$ Sexual & $\begin{array}{c}0.1036 \\
(0.0767)\end{array}$ & $\begin{array}{c}0.1227 \\
(0.1381)\end{array}$ & $\begin{array}{c}0.1965 \\
(0.2108)\end{array}$ \\
\hline Female $\times$ Racial $\times$ Sexual & $\begin{array}{c}-0.1104 \\
(0.1018)\end{array}$ & $\begin{array}{c}-0.1331 \\
(0.1834)\end{array}$ & $\begin{array}{l}-0.2471 \\
(0.2792)\end{array}$ \\
\hline Female $\times$ Veteran & $\begin{array}{c}0.0331 \\
(0.0394)\end{array}$ & $\begin{array}{c}0.0348 \\
(0.0766)\end{array}$ & $\begin{array}{c}0.0460 \\
(0.1232)\end{array}$ \\
\hline Racial $\times$ Veteran & $\begin{array}{c}-0.0018 \\
(0.0360)\end{array}$ & $\begin{array}{c}0.0017 \\
(0.0688)\end{array}$ & $\begin{array}{c}-0.0469 \\
(0.0927)\end{array}$ \\
\hline Female $\times$ Racial $\times$ Veteran & $\begin{array}{c}0.0630 \\
(0.0879)\end{array}$ & $\begin{array}{c}0.1420 \\
(0.1706)\end{array}$ & $\begin{array}{c}0.2908 \\
(0.2366)\end{array}$ \\
\hline Sexual $\times$ Veteran & $\begin{array}{c}0.0017 \\
(0.0777)\end{array}$ & $\begin{array}{l}-0.0410 \\
(0.1485)\end{array}$ & $\begin{array}{c}0.2603 \\
(0.2105)\end{array}$ \\
\hline Female $\times$ Sexual $\times$ Veteran & $\begin{array}{c}0.0819 \\
(0.2003)\end{array}$ & $\begin{array}{c}0.1804 \\
(0.3953)\end{array}$ & $\begin{array}{c}-0.3277 \\
(0.5213)\end{array}$ \\
\hline Racial $\times$ Sexual $\times$ Veteran & $\begin{array}{c}0.0694 \\
(0.2205)\end{array}$ & $\begin{array}{c}0.2060 \\
(0.4434)\end{array}$ & $\begin{array}{c}-0.1524 \\
(0.5158)\end{array}$ \\
\hline Female $\times$ Racial $\times$ Sexual $\times$ Veteran & $\begin{array}{c}-0.1015 \\
(0.3276)\end{array}$ & $\begin{array}{c}-0.2429 \\
(0.6405)\end{array}$ & $\begin{array}{c}1.5747 \\
(0.9121)\end{array}$ \\
\hline
\end{tabular}

Control Variables

\begin{tabular}{|c|c|c|c|c|}
\hline Age & $18-24$ & \multicolumn{3}{|c|}{ (reference category) } \\
\hline & $25-29$ & $\begin{array}{c}-0.1508 t \\
(0.0217)\end{array}$ & $\begin{array}{c}-0.2958 t \\
(0.0419)\end{array}$ & $\begin{array}{r}-0.2797 t \\
(0.0860)\end{array}$ \\
\hline & $30-34$ & $\begin{array}{c}-0.2362 t \\
(0.0206)\end{array}$ & $\begin{array}{c}-0.4626 t \\
(0.0406)\end{array}$ & $\begin{array}{r}-0.5621 t \\
(0.0782)\end{array}$ \\
\hline & $35-39$ & $\begin{array}{c}-0.3211 t \\
(0.0205)\end{array}$ & $\begin{array}{c}-0.6212 t \\
(0.0402)\end{array}$ & $\begin{array}{r}-0.6859 t \\
(0.0792)\end{array}$ \\
\hline & $40-44$ & $\begin{array}{c}-0.3897 t \\
(0.0203)\end{array}$ & $\begin{array}{c}-0.7311 t \\
(0.0396)\end{array}$ & $\begin{array}{r}-0.9937 t \\
(0.0745)\end{array}$ \\
\hline & $45-49$ & $\begin{array}{c}-0.4640 t \\
(0.0197)\end{array}$ & $\begin{array}{c}-0.8649 t \\
(0.0387)\end{array}$ & $\begin{array}{r}-1.2086 t \\
(0.0711)\end{array}$ \\
\hline & $50-54$ & $\begin{array}{c}-0.5132 t \\
(0.0191)\end{array}$ & $\begin{array}{c}-0.9509 t \\
(0.0378)\end{array}$ & $\begin{array}{r}-1.3549 t \\
(0.0672)\end{array}$ \\
\hline
\end{tabular}




\begin{tabular}{|c|c|c|c|}
\hline $55-59$ & $\begin{array}{c}-0.5913 t \\
(0.0187)\end{array}$ & $\begin{array}{c}-1.0869 t \\
(0.0367)\end{array}$ & $\begin{array}{r}-1.5179 t \\
(0.0666)\end{array}$ \\
\hline $60-64$ & $\begin{array}{c}-0.6241 t \\
(0.0183)\end{array}$ & $\begin{array}{c}-1.1482 t \\
(0.0361)\end{array}$ & $\begin{array}{r}-1.5618 t \\
(0.0656)\end{array}$ \\
\hline $65-69$ & $\begin{array}{c}-0.577 t \\
(0.0191)\end{array}$ & $\begin{array}{c}-1.0635 t \\
(0.0374)\end{array}$ & $\begin{array}{r}-1.4600 t \\
(0.0670)\end{array}$ \\
\hline $70-74$ & $\begin{array}{c}-0.5510 t \\
(0.0198)\end{array}$ & $\begin{array}{c}-1.0205 t \\
(0.0389)\end{array}$ & $\begin{array}{r}-1.3496 t \\
(0.0679)\end{array}$ \\
\hline $75-79$ & $\begin{array}{c}-0.6045 t \\
(0.0217)\end{array}$ & $\begin{array}{c}-1.1178 t \\
(0.0420)\end{array}$ & $\begin{array}{r}-1.3870 t \\
(0.0711)\end{array}$ \\
\hline $80+$ & $\begin{array}{c}-0.6682 t \\
(0.0217)\end{array}$ & $\begin{array}{c}-1.2358 t \\
(0.0421)\end{array}$ & $\begin{array}{r}-1.4692 t \\
(0.0695)\end{array}$ \\
\hline None/Kindergarten & \multicolumn{3}{|c|}{ (reference category) } \\
\hline Elementary & $\begin{array}{c}-0.4271 \\
(0.3326)\end{array}$ & $\begin{array}{c}-0.7579 \\
(0.6750)\end{array}$ & $\begin{array}{r}-0.5165 \\
(0.4293)\end{array}$ \\
\hline Some High School & $\begin{array}{c}-0.3155 \\
(0.3315)\end{array}$ & $\begin{array}{c}-0.5494 \\
(0.6730)\end{array}$ & $\begin{array}{r}-0.2332 \\
(0.4267) \\
\end{array}$ \\
\hline High School Graduate & $\begin{array}{c}-0.1145 \\
(0.3311)\end{array}$ & $\begin{array}{c}-0.1766 \\
(0.6725)\end{array}$ & $\begin{array}{c}0.1742 \\
(0.4259)\end{array}$ \\
\hline Some College & $\begin{array}{c}-0.0456 \\
(0.3311)\end{array}$ & $\begin{array}{l}-0.0410 \\
(0.6725)\end{array}$ & $\begin{array}{c}0.2732 \\
(0.4264)\end{array}$ \\
\hline College Graduate & $\begin{array}{c}0.1568 \\
(0.3311)\end{array}$ & $\begin{array}{c}0.3372 \\
(0.6725)\end{array}$ & $\begin{array}{c}0.7573 \\
(0.4272)\end{array}$ \\
\hline Income $<\$ 10,000$ & \multicolumn{3}{|c|}{ (reference category) } \\
\hline$<\$ 15,000$ & $\begin{array}{c}0.0435 \\
(0.0285)\end{array}$ & $\begin{array}{c}0.0890 \\
(0.0532)\end{array}$ & $\begin{array}{r}0.1753 t \\
(0.0549)\end{array}$ \\
\hline$<\$ 20,000$ & $\begin{array}{r}0.2038 t \\
(0.0273)\end{array}$ & $\begin{array}{r}0.3964 t \\
(0.0514)\end{array}$ & $\begin{array}{r}0.4634 \dagger \\
(0.0528)\end{array}$ \\
\hline$<\$ 25,000$ & $\begin{array}{r}0.3204 t \\
(0.0259)\end{array}$ & $\begin{array}{c}0.6079 t \\
(0.0481)\end{array}$ & $\begin{array}{r}0.7401 t \\
(0.0523)\end{array}$ \\
\hline$<\$ 35,000$ & $\begin{array}{r}0.4364 \dagger \\
(0.0246)\end{array}$ & $\begin{array}{r}0.8191 t \\
(0.0466)\end{array}$ & $\begin{array}{r}0.9682 t \\
(0.0513)\end{array}$ \\
\hline$<\$ 50,000$ & $\begin{array}{c}0.5841 t \\
(0.0239)\end{array}$ & $\begin{array}{c}1.0883 t \\
(0.0453)\end{array}$ & $\begin{array}{r}1.3624 \dagger \\
(0.0512)\end{array}$ \\
\hline$<\$ 75,000$ & $\begin{array}{c}0.6805 t \\
(0.0238)\end{array}$ & $\begin{array}{c}1.2653 t \\
(0.0455)\end{array}$ & $\begin{array}{r}1.5931 t \\
(0.0524)\end{array}$ \\
\hline$>\$ 75,000$ & $\begin{array}{c}0.8686 t \\
(0.0231)\end{array}$ & $\begin{array}{c}1.6261 t \\
(0.0444)\end{array}$ & $\begin{array}{r}2.0844 t \\
(0.0535)\end{array}$ \\
\hline
\end{tabular}

Summary Statistics

\begin{tabular}{|l|c|c|c|}
\hline Y-Intercept & $\begin{array}{c}3.3859 \dagger \\
(0.3300)\end{array}$ & $\begin{array}{c}3.1443 \dagger \\
(0.6701)\end{array}$ & $\begin{array}{r}1.3189 \dagger \\
(0.4293)\end{array}$ \\
\hline$R^{2}$ & 0.1618 & & \\
\hline
\end{tabular}




\section{B I B L I O G R A P H Y}

Acker, J. 2006. “Inequality Regimes - Gender, Class, and Race in Organizations.” Gender \& Society 20(4): 441-64.

Adler, N.E. and K. Newman. 2002. "Socioeconomic Disparities in Health: Pathways and Policies." Health Affairs 21(2): 60-76.

Assari, Shervin. 2014. "Veterans and Risk of Heart Disease in the United States: A Cohort with 20 Years of Follow Up." International Journal of Preventive Medicine 5(6): 703-709.

Balsam, K.F., E.D. Rothblum and T.P. Beauchaine. 2005. "Victimization Over the Life Span: A Comparison of Lesbian, Gay, Bisexual, and Heterosexual Siblings." Journal of Consulting and Clinical Psychology 73(5): 477-487.

Beaulieu, G.R., D.M. Latini, D.A. Helmer, C. Powers-James, C. Houlette and M.R. Kauth. 2015. “An Exploration of Returning Veterans' Sexual Health Issues Using a Brief Self-Report Measure.” Sexual Medicine 3(4): 247-294.

Bedi, U.S. and R. Arora. 2007. "Cardiovascular Manifestations of Posttraumatic Stress Disorder." Journal of the National Medical Association 99(6): 642-649.

Bennett, G.G., K.Y Wolin, E.L. Robinson, S. Fowler and C.L. Edwards. 2005. "Perceived Racial/Ethnic Harassment and Tobacco Use Among African American Young Adults.” American Journal of Public Health 95(2): 238-240.

Benson, H.E. 2013. "Seeking Support: Transgender Client Experiences with Mental Health Services." Journal of Feminist Family Therapy 25: 17-40. 
Blosnich, J.R., G.W. Farmer, J.G.L. Lee, V.M.B Silenzio and D.J. Bowen. 2010. "Health Inequalities Among Sexual Minority Adults: Evidence from Ten U.S. States, 2010." American Journal of Preventive Medicine 46(4): 337-349.

Blosnich, J.R., R. Bossarte, E. Silver and V. Silenzio. 2013a. "Health Care Utilization and Health Indicators among a National Sample of US Veterans in Same-Sex Partnerships." Military Medicine 178(2): 207-212.

Blosnich, J.R., M.M. Foynes and J.C. Shipherd. 2013b. "Health Disparities among Sexual Minority Women Veterans.” Journal of Womens Health 22 (7): 631-636.

Bourne, P.A. 2009. "Dichotomising poor self-reported health status: Using secondary cross-sectional survey data for Jamaica." North American Journal of Medical Sciences 1(6): 295-302.

Bowleg, L. 2008. "When Black Plus Lesbian Plus Woman Not Equal Black Lesbian Woman: The Methodological Challenges of Qualitative and Quantitative Intersectionality Research.” Sex Roles 59(5-6): 312-325.

Bowleg, L. 2013. “'Once You've Blended the Cake, You Can't Take the Parts Back to the Main Ingredients': Black Gay and Bisexual Men's Descriptions and Experiences of Intersectionality." Sex Roles 68(11-12): 754-767.

Brach, C. and I. Fraserirector. 2000. "Can Cultural Competency Reduce Racial and Ethnic Health Disparities? A Review and Conceptual Model." Medical Care Research and Review 57(S): 181-217.

Braveman, P.A. 2006. "Health Disparities and Health Equity: Concepts and Measurement." Annual Review of Public Health 27: 167-194. 
Braveman, P.A., C. Cubbin, S. Egerter, D.R. Williams and E. Pamuk. 2010.

"Socioeconomic Disparities in Health in the United States: What the Patterns Tell Us." American Journal of Public Health 100(1S): S186-S196.

Browne, I. and J. Misra. 2003. "The Intersection of Gender and Race in the Labor Market." Annual Review of Sociology 29: 487-513.

Burgard, S.A., S.D. Cochran and V.M. Mays 2005. "Alcohol and Tobacco Use Patterns Among Heterosexually and Homosexually Experienced California Women.” Drug and Alcohol Dependence 77(1): 61-70.

Burgess, D.J, M. Van Ryn, M. Crowley-Matoka and J. Malat. 2006. "Understanding the Provider Contribution to Race/Ethnicity Disparities in Pain Treatment: Insights from Dual Process Models of Stereotyping." Pain Medicine 7(2): 119-134.

Burks, D.J. 2011. "Lesbian, Gay, and Bisexual Victimization in the Military an Unintended Consequence of 'Don't Ask, Don't Tell'?’' American Psychologist 66(7): 604-613.

Byrd, R.C. 1991. The Senate, 1789-1989, Vol. 2. Washington, D.C.: Senate, United States Congress.

Carter, A. S. Borrero, C. Wessel, D.L. Washington, B. Bean-Mayberry and J. Corbelli. 2016. "Racial and Ethnic Health Care Disparities Among Women in the Veterans Affairs Healthcare System: A Systematic Review.” Women's Health Issues 26(4): 401-409.

Centers for Disease Control and Prevention (CDC). 2008. Community Health and Program Services (CHAPS): Health Disparities Among Racial/Ethnic Populations. Atlanta, GA: U.S. Department of Health and Human Services. 
Centers for Disease Control and Prevention (CDC). 2014. Behavioral Risk Factor Surveillance System Survey Questionnaire. Atlanta, GA: U.S. Department of Health and Human Services.

Cho, S., K.W. Crenshaw and L. McCall. 2013. "Toward a Field of Intersectionality Studies: Theory, Applications, and Praxis.” Signs 38(4): 785-810.

Chomitz, V.R., M.M. Slining, R.J. McGowan, S.E. Mitchell, G.F. Dawson and K.A. Hacker. 2009. "Is There a Relationship Between Physical Fitness and Academic Achievement? Positive Results from Public School Children in the Northeastern United States." Journal of School Health 79(1): 30-37.

Choo, H.Y. and M.M. Ferree. 2010. "Practicing Intersectionality in Sociological Research: A Critical Analysis of Inclusions, Interactions, and Institutions in the Study of Inequalities." Sociological Theory 28(2): 129-149.

Clark, R., N.B. Anderson, V.R. Clark and D.R. Williams. 1999. "Racism as a Stressor for African Americans: A Biopsychosocial Model.” The American Psychologist 54(10): 805-816.

Cochran, S.D., C. Keenan, C. Schober and V.M. Mays. 2000a. "Estimates of Alcohol Use and Clinical Treatment Needs Among LGBT Individuals in the United States." Journal of Consulting and Clinical Psychology 68(6): 1062-1071.

Cochran, S.D. and V.M. Mays. 2000b. Lifetime Prevalence of Suicide Symptoms and Affective Disorders Among Men Reporting Same-Sex Sexual Partners: Results from NHANES III. American Journal of Public Health 90(4): 573-578. 
Cochran, S.D. and V.M. Mays. 2000c. "Relation Between Psychiatric Syndromes and Behaviorally Defined Sexual Orientation in a Sample of the US Population.” American Journal of Epidemiology 151(5): 516-623.

Collins, P.H. 1989. "The Social Construction of Black Feminist Thought" Signs 14(4): 745-773.

Collins, P.H. 1990. Black Feminist Thought: Knowledge, Consciousness and the Politics of Empowerment. Boston: Unwin Hyman.

Collins, P.H. 1998. "The Tie That Binds: Race, Gender and US Violence." Ethnic and Racial Studies 21(5): 917-938.

Colvonen, P.J., T. Masino, S.P.A. Drummond, U.S. Myers, A.C. Angkaw and S.B. Norman. 2015. "Obstructive Sleep Apnea and Posttraumatic Stress Disorder among OEF/OIF/OND Veterans." Journal of Clinical Sleep Medicine 11(5): $513-518$.

Coughlin, S.S. 2011. "Post-traumatic Stress Disorder and Cardiovascular Disease." Open Cardiovascular Medicine Journal 5: 164-170.

Crenshaw, K. 1989. "Demarginalizing the Intersection of Race and Sex: A Black Feminist Critique of Antidiscrimination Doctrine, Feminist Theory and Antiracist Politics." The University of Chicago Legal Forum 140(1): 139-167. Crewnshaw, K. 1991. "Mapping the Margins: Intersectionality, Identity Politics, and Violence Against Women of Color.” Stanford Law Review 43(6): 1241-1299. Cummings, J.L. and P.B. Jackson. 2008. "Race, Gender, and Sex Disparities in SelfAssessed Health, 1974-2004" Research on Aging 30(2): 137-68. 
Dohrenwend, B.P. 1966. "Social Status and Psychological Disorder: An Issue of Substance and an Issue of Method." American Sociological Review 31(1): 14-34. Dohrenwend, B.P. 2000. "The Role of Adversity and Stress in Psychopathology: Some Evidence and Its Implications for Theory and Research.” Journal of Health and Social Behavior 41(1): 1-19.

Dominick, K.L., F.M. Ahem, C.H. Gold and D.A. Heller. 2004. "Health-related quality of life among older adults with arthritis." Health and Quality of Life Outcomes 2:5.

Ellickson, P, H. Saner and K.A. McGuigan. 1997. "Profiles of Violent Youth: Substance Use and Other Concurrent Problems." American Journal of Public Health, 87(6): 985-991.

Farrell, W.C. Jr. and C.K. Jones. 1988. "Recent Racial Incidents in Higher Education: A Preliminary Perspective." The Urban Review 20(3): 211-226.

Faulkner, A.H. and K. Cranston. 1998. "Correlates of Same-Sex Sexual Behavior in a Random Sample of Massachusetts High School Students." American Journal of Public Health 88(2): 262-266.

Feagin. J.R. 1991. “The Continuing Significance of Race: Antiblack Discrimination in Public Places.” American Sociological Review 56(1): 101-116.

Ferraro, K.F. 1980. "Self-Ratings of Health among the Old and the Old-Old." Journal of Health and Social Behavior 21 (December): 377-383.

Ferraro, K.F. and M.M. Farmer. 1999. "Utility of Health Data from Social Surveys: Is There a Gold Standard for Measuring Morbidity?” American Sociological Review 64 (April): 303-315. 
Fiscella, K., P. Franks, M.P. Doescher and B.G. Saver. 2002. "Disparities in Health Care by Race, Ethnicity, and Language Among the Insured: Findings from a National Sample." Medical Care 40(1): 52-59.

Flaskerud, J.H, J. Lesser, E. Dixon, N. Anderson, F. Conde, S. Kim, D. Koniak-Griffin, A. Strehlow, D. Tullmann and V. Inese. 2002. "Health Disparities Among Vulnerable Populations: Evolution of Knowledge Over Five Decades in Nursing Research Publications." Nursing Research 51(2): 74-85.

Fredriksen-Goldsen, K.I., H-J. Kim, S.E. Barkan, A. Muraco and C.P. Hoy-Ellis. 2013. "Health Disparities Among Lesbian, Gay, and Bisexual Older Adults: Results from a Population-Based Study." American Journal of Public Health 103(10): 1802-1809.

Garamone, J. 2011. "Pentagon Officials Explains Repeal Implementation.” American Forces Press Service, July 22.

Garnets, L., G.M. Herek and B. Levy. "Violence and Victimization of Lesbians and Gay Men: Mental Health Consequences." Journal of Interpersonal Violence 5(3): 366-383.

Gates, G. 2004. Gay Men and Lesbians in the US Military: Estimates from Census 2000. Washington, DC: The Urban Institute.

Gates, G.J. 2007. "Same-sex Couples and the Gay, Lesbian, Bisexual Population: New Estimates from the American Community Survey.” The Williams Institute on Sexual Orientation Law and Public Policy, UCLA School of Law.

Gilman, S.E., S.D. Cochran, V.M. Mays, M. Hughes, D. Ostrow and R.C. Kessler. 2001. "Risk of Psychiatric Disorders Among Individuals Reporting Same-Sex Sexual 
Partners in the National Comorbidity Survey." American Journal of Public Health 91(6): 933-939.

Goffman, E. 1963. Stigma: Notes on the Management of Spoiled Identity Englewood Cliffs, NJ: Prentice-Hall.

Goodman, A.H. 2000. "Why Genes Don’t Count (for Racial Differences in Health)." American Journal of Public Health 90(11): 1699-1702.

Gray, E. 2015. "Inside the Love Story that Changed the Gay Marriage Battle: Edith Windsor reflects on her life with late spouse, Thea Spyer, and the meaning of gay marriage.” TIME. June 26.

Green, A.R., D.R. Carney, D.J. Pallin, L.H. Ngo, K.L. Raymond, L.I. Iezzoni and M.R. Banaji. 2007. "Implicit Bias among Physicians and its Prediction of Thrombolysis Decisions for Black and White Patients.” Journal of General Internal Medicine 22(9): 1231-1238.

Grinberg, E. 2012. “Wisconsin’s Tammy Baldwin is first openly gay person elected to Senate." Cable News Network.

Haddock, C.K, W.S.C. Poston, S.A. Pyle, R.C. Klesges, M.W. Vander Weg, A. Peterson and M. Debon. 2006. "The Validity of Self-Rated Health as a Measure of Health Status Among Young Military Personnel: Evidence from a Cross-Sectional Survey." Health and Quality of Life Outcomes 4: 57-66.

Hatzenbuehler, M.L. 2009. “How Does Sexual Minority Stigma 'Get Under the Skin’? A Psychological Mediation Framework.” Psychological Bulletin 135: 707-730. Haley, R.W. 2003. "Excess Incidence of ALS in Young Gulf War Veterans.” Neurology 61(6): 750-756. 
Herek, G.M and K.T. Berrill. 1992. Hate Crimes: Confronting Violence Against Lesbians and Gay Men. Thousand Oaks, CA: Sage.

Herek, G.M., J.R. Gillis and J.C. Cogan. 1999. "Psychological Sequelae of Hate-Crime Victimization Among Lesbian, Gay, Bisexual and Transgender Adults.” Journal of Consulting and Clinical Psychology 67(6): 945-951.

Horner, R.D., K.G. Kamins, J.R. Feussner, S.C. Grambow, J. Hoff-Lindquist, Y. Harati, H. Mitsumoto, R. Pascuzzi, P.S. Spencer, R. Time, D. Howard, T.C. Smith, M.A.K. Ryan, C.J. Coffman and E.J. Kasarskis. 2003. “Occurrence of Amyotrophic Lateral Sclerosis among Gulf War Veterans.” Neurology 61(6): $742-749$.

Jackson, J.S., T.N. Brown, D.R. Williams, M. Torres, S.L. Sellers and K. Brown. 1996. "Racism and the Physical and Mental Health Status of African Americans: A Thirteen Year National Panel Study.” Ethnicity \& Disease 6(12): 132-147.

Jemel, A., M.J. Thun, E.E. Ward, S.J. Henley, V.E. Cokkinides and T.E. Murray. 2008. "Mortality from Leading Causes by Education and Race in the United States." American Journal of Preventive Medicine, 34(1): 1-8.

Kang, H.K., B.H. Natelson, C.M. Mahan, K.Y. Lee and F.M. Murphy. 2003. "PostTraumatic Stress Disorder and Chronic Fatigue Syndrome-like Illness among Gulf War Veterans: A Population-based Survey of 30,000 Veterans.” American Journal of Epidemiology 157(2): 141-148.

Keppel, K.G. 2007. “Ten Largest Racial and Ethnic Health Disparities in the United States Based on Healthy People 2010 Objectives.” American Journal of Epidemiology 166(1): 97-103. 
Kerrigan, M.F. 2012. “Transgender Discrimination in the Military: The New Don't Ask, Don't Tell." Psychology Public Policy and Law 18(3): 500-518.

Krieger, N. 1990 "Racial and Gender Discrimination: Risk Factors for High Blood Pressure?" Social Science \& Medicine 30(12): 1273-1281.

Krieger, N. J.T. Chen, P.D. Waterman, D.H. Rehkopf and S.V. Subramanian. 2003.

"Race/Ethnicity, Gender, and Monitoring Socioeconomic Gradients in Health: A Comparison of Area-Based Socioeconomic Measures-The Public Health Disparities Geocoding Project.” American Journal of Public Health 93(10): $1655-1671$.

Landrine, H. and E.A. Klonoff. 1996. "The Schedule of Racist Events: A Measure of Racial Discrimination and a Study of Its Negative Physical and Mental Health Consequences." Journal of Black Psychology 22(2): 144-168.

Lasser, K.E., D.U. Himmelstein and S. Woolhandler. 2006. “Access to Care, Health Status, and Health Disparities in the United States and Canada: Results of a Cross-National Population-Based Survey." American Journal of Public Health 96(7): 1300-1307.

LaVeist, T.A. 2005. Minority Populations and Health: An Introduction to Health Disparities in the United States. San Francisco, CA: Josey-Bass.

Leland, E. 2016. “North Carolina Doesn’t See a Need to Protect LGBTQ People. But We Found Victims Whose Stories Say Otherwise.” The Charlotte Observer, October 12.

Lew, H.L, J.D. Otis, C. Tun, R.D. Kerns, M.E. Clark, and D.X. Cifu. 2009. "Prevalence of Chronic Pain, Posttraumatic Stress Disorder, and Persistent Postconcussive 
Symptoms in OIF/OEF Veterans: Polytrauma Clinical Triad." Journal of Rehabilitation Research \& Development. 46(6): 697-702.

Lick, D.J., L.E. Durso and K.L. Johnson. 2013. "Minority Stress and Physical Health Among Sexual Minorities.” Perspectives on Psychological Science 8(5): 521548.

Lissitz, R. and Green, S. 1975. "Effect of the number of scale points on reliability: A Monte Carlo approach.” Journal of Applied Psychology 60(1): 10-13.

Martin, J. and A. Burns. 2016. "Abortion and Gay Marriage Are Absent from Donald Trump's Appeal to Evangelicals.” The New York Times, September 9.

Marx, K. and F. Engels. 1848. The Communist Manifesto.

Mattocks, K.M., A. Sadler, E.M. Yano, E.E. Krebs, L. Zephyrin, C. Brandt, R. Kimerling, T. Sandfort, M.E. Dichter, J.J. Weiss, J. Allison and S. Haskell. 2013. “Sexual Victimization, Health Status, and VA Healthcare Utilization among Lesbian and Bisexual OEF/OIF Veterans." Journal of General Internal Medicine 28: S604-S608.

Mays, V.M. and S.D. Cochran. 2001. "Mental Health Correlates of Perceived Discrimination Among Lesbian, Gay, and Bisexual Adults in the United States." American Journal of Public Health 91(11): 1869-1876.

Mays, V.M., A.K. Yancey, S.D. Cochran, M. Weber and J.E. Fielding. 2002.

"Heterogeneity of Health Disparities Among African American, Hispanic, and Asian American Women: Unrecognized Influences of Sexual Orientation.” American Journal of Public Health 92(4): 632-639.

McCall, L. 2005. “The Complexity of Intersectionality.” Signs 30(3): 1771-1800. 
McCarty, C.A., W.A. Mason, R. Kosterman, J.D. Hawkins, L.J. Lengua and E. McCauley. 2008. “Adolescent School Failure Predicts Later Depression Among Girls." Journal of Adolescent Health, 43(2): 180-187.

McKirnan, D.J and P.L. Peterson. 1988. "Stress, Expectancies, and Vulnerability to Substance Abuse: A Test of a Model Among Homosexual Men.” Journal of Abnormal Psychology 97(4): 461-466.

Meyer, I.H. 1995. "Minority Stress and Mental Health in Gay Men.” Journal of Health and Social Behavior 36(1): 38-56.

Meyer, I.H. 2003. "Prejudice, Social Stress, and Mental Health in Lesbian, Gay, and Bisexual Populations: Conceptual Issues and Research Evidence.” Psychological Bulletin 129(5): 674-97.

Miilunpalo, S., I. Vuori, P. Oja, M. Pasanen, H. Urponen. 1997. “Self-Rated Health Status as a Health Measure: The Predictive Value of Self-Reported Health Status on the Use of Physician Services and on Mortality in the Working-Age Population." Journal of Clinical Epidemiology 50(5): 517-528.

Moradi, B. 2009. "Sexual Orientation Disclosure, Concealment, Harassment, and Military Cohesion: Perceptions of LGBT Military Veterans.” Military Psychology 21(4): 513-33.

Mustanski, B. 2015. "Future Directions in Research on Sexual Minority Adolescent Mental, Behavioral, and Sexual Health.” Journal of Clinical Child and Adolescent Psychology 44(1): 204-219.

Nash, J.C. 2008. "Re-Thinking Intersectionality" Feminist Review (89): 1-15. 
National Institute on Drug Abuse (NIDA). 2013. DrugFacts - Substance Abuse in the Military. Bethesda, MD: National Institutes of Health, U.S. Department of Health and Human Services.

National Institutes of Health (NIH). 2010. FACT SHEET - Health Disparities. Bethesda, MD: U.S. Department of Health and Human Services.

Nayback, A. M. 2008. “Health Disparities in Military Veterans with PTSD: Influential Sociocultural Factors.” Journal of Psychosocial Nursing 46(6): 43-51.

Newcomb, M.E. M. Birkett, H.L. Corliss and B. Mustanski. 2014. "Sexual Orientation, Gender, and Racial Differences in Illicit Drug Use in a Sample of US High School Students.” American Journal of Public Health 104(2): 304-310.

Nolen-Hoeksema, S. 1991. "Responses to Depression and their Effects on the Duration of Depressive Episodes.” Journal of Abnormal Psychology 100(4): 569-82.

Nolen-Hoeksema, S., B.E. Wisco and S. Lyubomirsky. 2008. "Rethinking Rumination." Perspectives on Psychological Science 3(5): 400-424.

O’Brien, C., J. Keith and L. Shoemaker. 2015. “Don't Tell: Military Culture and Male Rape.” Psychological Services. 12(4): 357-365.

Obergefell v. Hodges. 576 U.S. __ (2015).

Orsi, J.M., H. Margellos-Anast and S. Whitman. 2010. "Black-White Health Disparities in the United States and Chicago: A 15-Year Progress Analysis.” American Journal of Public Health 100(2): 349-356.

Pachankis, J.E. 2007. “The Psychological Implications of Concealing a Stigma: A Cognitive-Affective-Behavioral Model.” Psychological Bulletin 133(2): 328345. 
Pachankis, J.E., M.R. Goldfried and M. Ramrattan. 2008. "Extension of the Rejection Sensitivity Soncstruct to the Interpersonal Functioning of Gay Men.” Journal of Consulting and Clinical Psychology 76(2): 306-317.

Parrish, K. 2013. "Same-sex Couples Can Claim New Benefits by October.” American Forces Press Service, February 11.

Pascoe, E.A. and L.S. Richman. 2009. "Perceived Discrimination and Health: A MetaAnalytic Review.” Psychological Bulletin 135(4): 531-554.

Peters, J.W. 2016. "Marco Rubio Warns Christian Conservatives of the Costs of Gay Intolerance." The New York Times, August 12.

Phillips, D. 2015. "Ousted as Gay, Aging Veterans Are Battling Again for Honorable Discharges.” The New York Times, September 6.

Pietrzak, R.H. and S.M. Southwick. 2011. "Psychological Resilience in OEF-OIF Veterans: Application of a Novel Classification Approach and Examination of Demographic and Psychosocial Correlates." Journal of Affective Disorders 133(3): 560-568.

Polusny, M.A., M.J. Kumpula, L.A. Meis, C.R. Erbes, P.A. Arbisi, M. Murdoch, P. Thuras, S.M. Kehle-Forbes and A.K. Johnson. 2014. "Gender Differences in the Effects of Deployment-Related Stressors and Pre-Deployment Risk Factors on the Development of PTSD Symptoms in National Guard Soldiers Deployed to Iraq and Afghanistan.” Journal of Psychiatric Research 49(2): 1-9.

Purdie-Vaughns, V. and R.P. Eibach. 2008. "Intersectional Invisibility: The Distinctive Advantages and Disadvantages of Multiple Subordinate-Group Identities." Sex Roles 59(5-6): 377-391. 
Reichmann, W.M., J.N. Katz, C.L. Kessler, J.M. Jordan and E. Losina. 2009.

"Determinants of Self-Reported Health Status in a Population-Based Sample of Persons with Radiographic Knee Osteoarthritis.” Arthritis Care \& Research 61(8): 1046-1053.

Reilly, K. 2016. “Caitlyn Jenner is 'Going to Be Using the Men's Shower,' North Carolina’s Governor Says.” TIME, October 12.

Rein, L. 2015. “After Court Ruling, Gay Veterans Get Marriage Benefits They Were Denied." The Washington Post, July 2.

Russell, S.T. and K. Joyner. 2001. “Adolescent Sexual Orientation and Suicide Risk: Evidence from a National Study." American Journal of Public Health 91(8): $1276-1281$.

Savage, C. 2013. "V.A. to Provide Spousal Benefits to Gays, Administration Says." The New York Times, September 4.

Schumm, J.A. and K.M. Chard. 2012. "Alcohol and Stress in the Military." Alcohol Research 34(4): 401-407.

Seaver, M.R., K.M. Freund, L.M. Wright, J. Tjia and S.M. Frayne. 2008. "Healthcare Preferences Among Lesbians: a focus group analysis.” Journal of Womens Health 17(2): 215-225.

Sherman, M.D., M.R. Kauth, J.C. Shipherd and R.L. Street, Jr. 2014. “Communication between VA Providers and Sexual and Gender Minority Veterans: A Pilot Study." Psychological Services 11(2): 235-242.

Shilts, R. 1993/2005. Conduct Unbecoming: Gays and Lesbians in the U.S. Military. New York: St. Martin’s Griffin. 
Shipherd, J.C., L. Mizock, S. Maguen and K.E. Green. 2012. "Male-to-Female Transgender Veterans and VA Health Care Utilization.” International Journal of Sexual Health 24(1): 78-87.

Simpson, T.L., K.F. Balsam, B.N. Cochran, K. Lehavot and S.D. Gold. 2013. "Veterans Administration Health Care Utilization among Sexual Minority Veterans.” Psychological Services 10(2): 223-232.

Smedley, B.D., A.Y. Stith and A.R. Nelson. 2002. Unequal Treatment: Confronting Racial and Ethnic Disparities in Health Care. National Academies Press.

Stuart, S.M., M.L. Sachs, J.R. Lidicker, S.N. Brett, A.R. Wright and J.R. Libonati. 2008. "Decreases Scholastic Achievement in Overweight Middle School Students." Obesity 16(7): 1535-1538.

Thompson, V.L. 1996. "Perceived Experiences of Racism as Stressful Life Events." Community Mental Health 32(3): 223-233.

Tomes, E., A. Brown, K. Semenya and J. Simpson. 1990. “Depression in Black Women of Low Socioeconomic Status: Psychological Factors and Nursing Diagnosis.” Journal of National Black Nurses Association 4(2): 37-46.

U.S. Bureau of the Census (Census). 2010. “2010 Census of Population, Public Law 94171 Data File.” Suitland, MD: U.S. Department of Commerce, Economics and Statistics Administration.

U.S. Bureau of the Census (Census). 2013. “American Community Survey (ACS) and Puerto Rico Community Survey (PRCS), 5-Year Estimates.” Suitland, MD: U.S. Department of Commerce, Economics and Statistics Administration. 
U.S. Department of Defense (DOD). 1993. Qualification Standards for Enlistment, Appointment, and Induction (DOD Instruction 1304.26). Washington, D.C.: U.S. Department of Defense, Office of the Secretary of Defense.

U.S. Department of Defense (DOD). 2010. Medical Standards for Appointment, Enlistment, or Induction in the Military Services (DOD Instruction 6130.03). Washington, DC: U.S. Department of Defense, Under Secretary of Defense for Personnel and Readiness.

U.S. Department of Veterans Affairs (VA). 2014. Veteran Population Project Model 2014. Washington, D.C.: U.S. Department of Veterans Affairs, Office of the Actuary.

U.S. Department of Veterans Affairs (VA). 2016. Suicide Among Veterans and Other Americans, 2001-2014. Washington, D.C.: U.S. Department of Veterans Affairs, Office of Suicide Prevention.

United States v. Marcum, 60 M.J. 198 (C.A.A.F. 2004).

United States v. Stirewalt, 69 M.J. 287 (C.A.A.F. 2004).

van Assendelft, L and J.D. Schultz. 1998. Encyclopedia of Women in American Politics. van Ryn, M. and J. Burke. 2000. "The Effect of Patient Race and Socio-Economic Status on Physicians' Perception of Patients.” Social Science \& Medicine 50(6): 813828.

Vanden Brook, T. 2010. "VA Sees Sharp Rise in Apnea Cases." USA Today, June 7. Wax-Thibodeaux, E. 2014. “'Don't Ask, Don't Tell' is Over. But Challenges Remain for LGBT Veterans and Service Members.” The Washington Post, September 20. 
Williams, D.R. 1997. "Racial Differences in Physical and Mental Health: Socioeconomic Status, Stress and Discrimination.” Journal of Health Psychology 2(3): $335-351$.

Williams, D.R. 1999. “Race, Socioeconomic Status, and Health: The Added Effects of Racism and Discrimination." Socioeconomic Status and Health in Industrial Nations: Social, Psychological, and Biological Pathways 896: 173-88.

Williams, D.R., H.W. Neighbors and J.S. Jackson. 2003. "Racial/Ethnic Discrimination and Health: Findings from Community Studies.” American Journal of Public Health 93(2): 200-208.

Williams, R. 2006. “Generalized Ordered Logit/ Partial Proportional Odds Models for Ordinal Dependent Variables.” The Stata Journal 6(1): 58-82.

Williams, R. 2016. "Understanding and interpreting generalized ordered logit models." The Journal of Mathematical Sociology 40:1, 7-20.

Williamson, I.R. 2000. “Internalized Homophobia and Health Issues Affecting Lesbians and Gay Men.” Health Education Research 15(1): 97-107.

Wirth, L. 1941. "Morale and Minority Groups.” American Journal of Sociology. 47(3): $415-433$. 